Academic Platform Journal of Engineering and Science

\title{
Bitkilerde Tuz Toleransının Fizyolojik ve Biyokimyasal Bileșenleri
}

\author{
${ }^{* 1}$ Ali Doğru, ${ }^{2}$ Serkan Canavar \\ ${ }^{1}$ Sakarya Üniversitesi Fen Edebiyat Fakültesi Biyoloji Bölümü Esentepe Sakarya, adogru@ sakarya.edu.tr, \\ ${ }^{2}$ Sakarya Üniversitesi Fen Edebiyat Fakültesi Biyoloji Bölümü Esentepe Sakarya, serkancanavar200@gmail.com, \\ Araştırma Makalesi \\ Geliş Tarihi: 18.03.2019 \\ Kabul Tarihi: 21.08.2019
}

\section{Öz}

Tuz stresi dünyada tarımsal verimliliği kısıtlayan en önemli abiyotik stres faktörlerinden biridir. Toprak tuzluluğu bitkilerde fotosentetik pigment miktarını ve fotosentetik aktiviteyi, sonuçta da büyüme hızını azaltabilmektedir. Ancak bazı bitki türleri tuza toleranslıdır ve yüksek tuz konsantrasyonlarında yaşam döngülerini tamamlayabilir. Tuza toleranslı bitkiler çözünür karbohidratlar, çözünür proteinler, bazı amino asitler, kuaterner amonyum bileşikleri ve polioller gibi bazı organik bileşikleri dokularında biriktirebilir. Bu organik bileşikler tuza toleranslı bitkilerde su kaybını minimum seviyeye indirmekten, hücresel ozmoregülasyonun sağlanmasından ve aktif oksijen türlerinin detoksifikasyonundan sorumludur. Tuz stresi aynı zamanda bitkilerde aktif oksijen türlerinin oluşum hızını artırarak oksidatif strese neden olabilir. Bu durumda tuza toleranslı bitkilerin etkili bir antioksidant sisteme sahip olması gerekir. Bu derlemede, tuz stresi altındaki bitkilerde meydana gelen bazı fizyolojik ve biyokimyasal değişimlerle tuz toleransı arasındaki ilişki tartışılmıştır.

Anahtar Kelimeler: Antioksidant sistem, bitki büyümesi, tuz stresi, tuz toleransı

\section{Physiological and Biochemical Components of Salt Tolerance in Plants}

\author{
*1 Ali Doğru, ${ }^{2}$ Serkan Canavar \\ ${ }^{1}$ Sakarya Üniversity Faculty of Arts and Science Department of Biology Esentepe Sakarya, adogru@ sakarya.edu.tr \\ ${ }^{2}$ Sakarya Üniversity Faculty of Arts and Science Department of Biology Esentepe Sakarya, serkancanavar200@ gmail.com
}

\begin{abstract}
Salt stress is one of the abiotic stress factors that restricting agricultural productivity throughout the world. Soil salinity may lead to a decrease in the amount of photosynthetic pigments and photosynthetic activity, and eventually to slow down the growth rate in plants. However, some plant species are salt-tolerant and have the ability to complete their life cycle under high salt concentrations. Salt-tolerant plants may accumulate certain organic substances in their tissues, such as soluble carbohydrates, soluble proteins, some aminoacids, quaternary ammonium compounds and polyols. These organic substances are responsible for minimizing water loss, providing cellular osmoregulation and detoxification of active oxygen species (AOS) in salt-tolerant plants. Salt stress could also result in oxidative stress by accelerating AOS formation in plants. Therefore, salt-tolerant plants must have an effective antioxidant activity. In this review, the relationship between salt tolerance and some physiological and biochemical changes in plants under salt stress is discussed.
\end{abstract}

Keywords: Antioxidant system, plant growth, salt stress, salt tolerance

\section{GíRiș}

Tuz stresi bitkilerde büyüme ve gelişmeyi olumsuz yönde etkileyen en önemli abiyotik stres faktörlerinden biridir [1]. Tuzlu topraklarla ilgili ilk kayitlar MÖ 2400' lü yıllarda Dicle-Fırat alüvyon ovasındaki topraklara aittir [2]. Tuzluluktan etkilenen topraklara nemli tropik bölgelerden kutuplara kadar çok çeşitli iklim rejimlerinde rastlanabilir. Aynı zamanda tuzlanma deniz seviyesinin altındaki (Ölüdeniz) ve binlerce metre üzerindeki (Tibet Platosu) topraklarda da görülmektedir. Sonuç olarak toprak tuzluluğu sadece kurak ve yarı kurak bölgelerle sinırlı bir kavram değildir [3]. Yeryüzündeki tüm topraklar, kalitesi ve kaynağı ne olursa olsun tüm su kaynakları mutlaka belli oranda tuz

*Sorumlu Yazar: Sakarya Üniversitesi Fen Edebiyat Fakültesi Biyoloji Bölümü Esentepe Sakarya, adogru@ sakarya.edu.tr, Tel: +90 02642956202 
içermektedir. Rhoades (1988), Avustralya, Çin, Mısır, Hindistan, Irak, Meksika, Pakistan, Rusya ve Suriye ile birlikte ülkemiz topraklarının da ciddi anlamda tuz stresi tehlikesi ile karşı karşıya olduğunu bildirmiştir [4]. Yurdumuz topraklarının yaklaşık 1.5 milyon hektarlık kısmı tuzluluk sorunuyla karşı karşıyadır. Yeryüzünde ise 800 milyon hektardan fazla alan tuzluluktan etkilenmektedir ve bu alan dünyanın tüm karasal alanlarının \%6' sından fazladır. Kuru tarım yapılan 150 milyon hektarlık alanın 32 milyon hektarı çeşitli oranlarda tuzluluk tehdidi altındadır. Sulama yapılan 230 milyon hektar alanın 45 milyon hektarı tuzdan etkilenmektedir. Ekilebilir alanlarda gözlenen bu boyuttaki tuz birikiminin, özellikle ürün verimi ve kalitesindeki azalmaya bağlı olarak büyük ekonomik kayıplara neden olacağı ön görülmektedir [5].

Farklı bitki türlerinin yanı sıra aynı türe ait farklı genotiplerin de tuza tolerans dereceleri farklı olabilmektedir. Günümüzde bitkilerin tuza tolerans derecelerinin ortaya çıkarılmasında büyüme ve fotosentez hızı [6, 7, 8, 9], dokulardaki su [10], çözünür karbohidrat [11], çözünür protein [12], aminoasit [13], kuaterner amonyum bileşikleri [14], poliol [15], lipid [16] iyon [17] ve hormon miktarları [17, 18, 19, 20, 21, 22] [22, 13] ile antioksidant enzim aktivitelerindeki [23] değişimler gibi fizyolojik ve biyokimyasal parametreler kriter olarak kullanılmaktadır.

$\mathrm{Bu}$ derlemede, toprakların tuzlanma nedenleri ve tuzluluk tiplerinin yanı sıra tuz stresi altındaki bitkilerde meydana gelen bazı fizyolojik ve biyokimyasal değişimlerle tuz toleransı arasındaki ilişki hakkında bilgi verilmiştir.

\section{TOPRAK TUZLULUĞUNUN TIPLERİ VE SEBEPLERİ}

Bir toprağın tuzlu olarak tanımlanabilmesi için o topraktaki çözünür tuz konsantrasyonunun bitki büyümesini olumsuz yönde etkileyecek kadar artış göstermesi gerekir. Topraklardaki tuz konsantrasyonu toprak çözeltisinin elektriksel iletkenlik değeri ile ölçülmektedir. Günümüzde eğer bir toprağın elektriksel iletkenlik değeri $4 \mathrm{dS} \mathrm{m}^{-1}$ veya daha fazla ise o toprak tuzlanmış olarak kabul edilmektedir. $\mathrm{Bu}$ iletkenlik değeri yaklaşık olarak $40 \mathrm{mM}$ ' lik bir tuz konsantrasyonuna karşılık gelmektedir [24].

Tuz bileşiklerinin hem toprakta hem de yeraltı sularında uzun bir süre boyunca birikim göstermesi sonucu oluşan tuzluluğa "primer tuzluluk" denir (Şekil 1). Primer tuzluluğun iki tane doğal sebebi vardır. Bunlardan birincisi, çözünür tuz bileşiklerini içeren ana kaya materyalinin aşınmasıdır. $\mathrm{Bu}$ aşınmma sonucunda kayaların bileşimindeki klorür, sülfat ve karbonat formundaki tuz bileşikleri toprağın yapısına katılmaktadır. $\mathrm{Bu}$ tuz bileşikleri arasında çözünürlük derecesi en fazla olanı sodyum klorürdür $(\mathrm{NaCl})$ [25]. İkinci sebep ise deniz ve okyanus suyunun yapısındaki tuz bileşiklerinin yağmur ve rüzgar vasıtasıyla karalara taşınarak toprağın yapısına katılmasıdır. Genellikle iç kesimlere rüzgarla taşınan bu tip tuzlara "siklik tuzlar" adı verilir ve bunlar çoğunlukla sodyum klorür formundadır. Yağmur suyu da 6-50 ppm civarında tuz içerir. Ancak yağmur suyundaki tuz miktarı kıyıdan uzaklaştıkça azalır. 10 ppm civarında tuz içeren yağmur suyu vasıtasıyla karalara yılda yaklaşı $10 \mathrm{~kg} \mathrm{ha}^{-1}$ tuz ilavesinin gerçekleştiği tahmin edilmektedir. "Sekonder tuzlanma" ise insan aktiviteleri sonucunda, yağış miktarı ile bitkilerin kullandığı su miktarı arasındaki dengenin, yani topraktaki hidrolojik dengenin değişmesi sonucu ortaya çıkar (Şekil 1). Bunun en yaygın sebepleri arasında arazilerdeki çok yıllık bitkiler yerine tek yıllık bitki yoğunluğunun artırılması, yetersiz drenaj ve sulama sularının yapısındaki tuz bileşikleri sayılabilir. İnsan etkisinin olmadığı durumlarda kurak ve yarı kurak bölgelerde yağış miktarı ile bitkiler tarafindan kullanılan su miktarı arasında bir denge vardır [25]. Daha derin kök sistemine sahip olan çok yıllık bitkiler, topraktaki taban suyunun yüzeyin daha altında bulunmasını sağlar. Bitki örtüsünün değiştirilmesi ve sulama olayı ile denge bozulur ve topraktaki su miktarı bitkilerin kullanabileceği seviyenin üzerine çıkar. Sonuçta taban suyunun yükselmesiyle toprağın daha alt tabakalarında bulunan tuz bileșikleri kök bölgesine taşınır. Bitkiler suyu kökleriyle aldıkça toprak daha tuzlu bir hale dönüşür. Taban suyu yükselmeye devam ettikçe tuz bileşikleri de yükselir ve toprak yüzeyinden suyun buharlaşmasıyla tuzlar toprak yüzeyinde bir tabaka oluşturmaya başlar. Tuzlar aynı zamanda toprağın derinliklerine doğru inerek yeraltı sularının yapısına da girebilir [25]. Tuzlu topraklarda $\mathrm{Na}^{+}, \mathrm{Ca}^{+2}, \mathrm{Mg}^{+2}, \mathrm{~K}^{+}$ katyonlarının yanı sıra, $\mathrm{Cl}^{-}, \mathrm{SO}_{4}^{-2}$ (sülfat), $\mathrm{HCO}_{3}$ (bikarbonat), $\mathrm{CO}_{3}^{-2}$ (karbonat) ve $\mathrm{NO}_{3}^{-}$(nitrat) anyonları bulunmaktadır [26].

Sulamanın yapıldığı birçok bölgede, hem aşırı sulamadan hem de zayıf drenajdan dolayı taban suyu yükselir. Sulama suyunun kalitesi ne kadar yüksek olursa olsun toprağın yapısına 200-500 ppm civarında tuzun katılmasına neden olur. Örneğin 500 ppm civarında tuz içeren sulama suyu, her $1,000 \mathrm{~m}^{3}$ suyla birlikte toprağa yılda 0.5 ton tuz ilavesine yol açar. Tarımsal bitkilerin her yıl hektar başına yaklaşık 6,000$10,000 \mathrm{~m}^{3}$ suya gereksinim duyduğu düşünülürse, bir hektarlık alana yılda yaklaşık 3-5 ton tuz girişi olur. Tarımsal bitkiler aracılığı ile topraktan uzaklaştırılan tuz miktarı ihmal edilecek kadar az olduğundan, kök bölgesinde sürekli bir tuz birikimi meydana gelir ve bu tuzun uzaklaştırılabilmesi için bitkilerin gereksinim duyduğundan çok daha fazla suyun toprağa verilmesi gerekir. Eğer böyle bir ortamda drenaj da zayıf ise su fazlalığı tuzların kök bölgesine taşınmasına sebep olur. Bitkilerin, uygulanan suyun tamamını kullanamaması durumunda da su baskınları gözlenir [25]. 


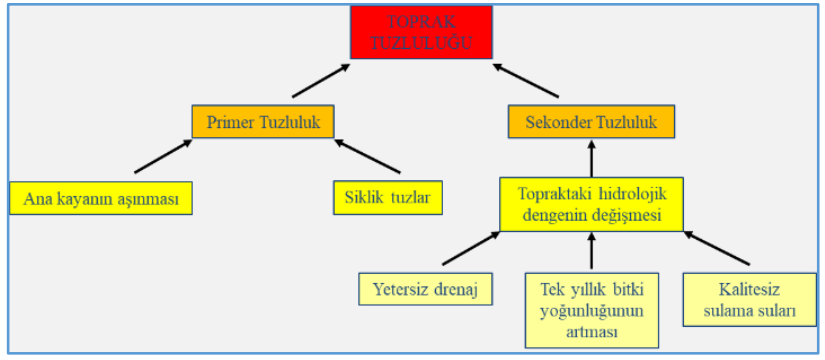

Şekil 1. Toprak tuzluluğunun nedenleri ve tipleri.

\section{BİTKILERDE TUZ TOLERANSI}

Parida ve Das (2005) tuz toleransını, bir bitkinin yüksek tuz konsantrasyonları altında büyüyebilme ve yaşam döngüsünü tamamlayabilme yeteneği olarak tanımlamıştır [6]. Tuzluluğun bitkiler üzerindeki zararlı etkileri arasında toprak çözeltisinin ozmotik potansiyelini düşürerek fizyolojik kuraklığa neden olması, mineral madde beslenmesi konusunda dengesizliğe neden olması ve tuz iyonlarının spesifik toksik etkisi sayılabilir [27]. Bunların hepsi bitki büyümesi ve gelişmesi üzerinde fizyolojik, biyokimyasal ve moleküler seviyede çok yönlü olumsuz etkilere yol açmaktadır [28]. Birçok bitki türü tuz stresine oldukça duyarlıdır ve bu grupta yer alan bitkilere genel olarak "glikofit" adı verilir. Glikofit bitkiler genellikle 100200 mM' lik tuz konsantrasyonlarında bile canlılıklarını sürdüremez. Ancak "halofitler" 300-400 mM gibi oldukça yüksek tuz konsantrasyonuna sahip olan topraklarda büyüyebilen ve yaşam döngülerini tamamlayabilen bitki türlerini içermektedir. Halofit bitkiler filogenetik adaptasyon süreçleri boyunca tuz toleransı geliştirdikleri için aşırı tuzlu topraklarda büyüyebilmektedir.

Tuz stresine duyarlı ve toleranslı olan bitkilerde, yapraklardaki tuz konsantrasyonunun toksik seviyeye ulaşması, tuz stresinin şiddetine ve bitki türüne bağlı olarak haftalar hatta aylar almaktadır. Bu konuda tuz stresinin ozmotik ve iyon etkisinden kaynaklanan "iki fazlı etki modeli” ş̧ekil 2' de gösterilmiştir [29].

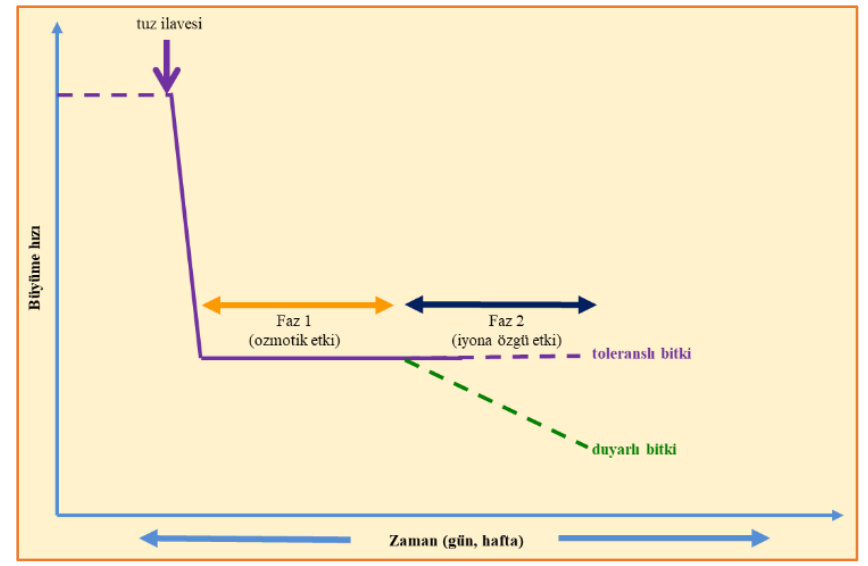

Şekil 2. Tuz stresi altındaki bitkilerde iki fazlı etki modeli [29].
Buna göre birinci fazda (ozmotik faz) tuz stresine hem duyarlı hem de toleranslı olan bitkilerde büyüme hızı, tuzun neden olduğu ozmotik etkiden dolayı yavaşlamaktadır. Ozmotik faz, kök çevresindeki tuz konsantrasyonunun bitkinin topraktan su almasını zorlaştıracak eşik değere ulaşmasından hemen sonra başlamakta ve sonuçta gövdenin büyüme hızı önemli oranda azalmaktadır. Bu şartlar altında bitkinin verdiği ilk cevap stomaların kapatılmasıdır. Ancak hem atmosferle yaprak hücreleri arasındaki su potansiyeli farkına hem de karbon fiksasyonunun devam etmesine duyulan gereksinim yüzünden bu uzun vadeli bir tolerans cevabı olarak kabul edilmemektedir [30]. Gövde büyümesinin kök büyümesine göre tuzun neden olduğu ozmotik strese daha duyarlı olmasının nedeni, muhtemelen yaprak alanındaki azalmanın bitkinin su kullanım oranını azaltmasıdır [30]. Tuz stresine duyarlı olan bitkilerde yaprak büyümesindeki inhibisyonunun sebeplerinden birinin, kalsiyum iyonlarının kök ksilemine yüklenmesinin engellenmesi olabileceği ileri sürülmüştür [31]. İkinci evrede (iyon etkisi evresi) ise transpirasyon akımı ile taşınan sodyum iyonlarının yapraklarda birikim göstermesi söz konusudur [32]. Sodyum birikimi artık büyümesi durmuş ve hücre öz suyundaki tuz konsantrasyonunu seyreltme yeteneğini kaybetmiş olan yaşı yapraklarda toksik etkiler yapabilmektedir. Tuz stresi altındaki bir bitkide eğer yaşlı yaprakların ölme oranı yeni yaprakların oluşma oranından yüksekse, fotosentetik aktivite genç yaprakların karbohidrat gereksinimini karşılayamamakta ve sonuç olarak büyüme hızı azalmaktadır [30]. Fotosentetik dokulardaki sodyum birikiminin, karbon fiksasyon reaksiyonları ile klorofil ve karotenoid sentezi ile ilgili enzimlerin aktivitesini azalttığ rapor edilmiştir [33]. Tuza duyarlı bitkilerde ayrica fotosentetik aktivitenin azalması, bazı aktif oksijen türlerinin (AOT) oluşum hızını artırmakta ve AOT' ler de hücresel hasarlara yol açmaktadır [34].

Aşağıda tuz stresinin bitkilerdeki bazı büyüme parametreleri ve metabolik olaylar üzerindeki etkileri ve bunların tuz toleransı ile etkileşimleri verilmiştir.

\subsection{Bitki Büyümesi}

Tuz stresinin gözlemlenen ilk etkilerinden biri bitkilerde büyüme hızının azalmasıdır. Munns (2002), tuz uygulamasından çok kısa bir süre sonra bitki hücrelerinin su kaybederek hacimlerinin azaldığını bildirmiştir [32]. Daha sonra hücreler orjinal boyutlarını tekrar kazanmakla birlikte, kök ve yaprakların büyüme hızının kontrol bitkilerine göre düşük olduğunu rapor etmiştir [32]. Tuz stresine maruz kalma süresi arttıkça meristematik hücrelerdeki mitoz bölünme hızı azalmakta, vejetatif ve generatif gelişmede farklılıklar ortaya çıkmaktadır [32]. Tek yıllık bitkilerde bu değişimlerin meydana gelmesi için türe ve tuz stresinin şiddetine bağlı olarak günlerle veya haftalarla ifade edilecek bir süre gerekirken, çok yıllık bitkilerde bu süre çok daha uzundur. Bitkilerin tuz stresine erken fide döneminde çok daha duyarlı oldukları bilinmektedir. Örneğin Hasanuzzaman ve arkadaşları (2009) yaptıkları bir çalışmada, tuz stresinin pirinç bitkilerinde erken fide 
döneminde toplam bitki boyunu ve yaprak alanını önemli derecede azalttığını belirlemişlerdir [7]. Papp ve arkadaşları (1983), şeker pancarı bitkisinde mitoz bölünme hızının yaprakların ilk oluşum evresinde tuz stresinden etkilenmediğini, ancak yaprak genişlemesi evresinde belli oranda inhibe edildiğini rapor etmiş̧ir [35]. Doğru (2014) tuz stresinin bazı mısır genotiplerinde kök, bazılarında ise gövde büyümesini inhibe ettiğini ve bunun tuz alınımı ve taşınımı konusunda genotipe bağlı farklılıklardan kaynaklanmış olabileceğini ileri sürmüştür [8]. Amaranthus tricolor' da yapılan bir çalışmada, uygulanan tuz konsantrasyonunun artışına bağlı olarak yaprak genişleme hızının azaldığ belirlenmiştir [36]. Zaimoğlu ve Doğru (2016) ise tuz stresinin bazı mısır genotiplerinde gövde büyümesini köklere göre daha belirgin şekilde inhibe ettiğini ve gövde büyümesinin tuza daha duyarlı olduğunu ortaya çıkarmıştır [9].

Tuz stresi bitkilerde çeşitli organların taze ve kuru ağırlıkları üzerinde de etkili olmaktadır [37]. Örneğin Raphanus sativus' da tuz stresi uygulamaları sonucu toplam bitki kuru ağırlığının azaldığı belirlenmiştir [38]. Kurban ve arkadaşları (1999) ise düşük tuz konsantrasyonlarının (50 mM) Alhagi pseudoalhagi bitkisinde toplam bitki ağırlığını artırdığını, ancak 200 ve 300 mM' lık tuz uygulamalarının azalttığını bildirmiştir [39]. Yapılan diğer bir çalışmada domates bitkilerinde artan tuz konsantrasyonlarına paralel olarak kök ve gövde büyümesi, gövde ağırlı̆̆ı, bitki başına yaprak sayısı ve kök yüzey alanı gibi parametrelerde kontrole göre önemli derecede azalmanın meydana geldiği rapor edilmiş̧ir [40]. Meloni ve arkadaşları (2001), tuz stresi altındaki pamuk bitkilerinde kök, gövde ve yaprak ağırlıklarının azaldığını gözlemlemiştir [41]. Zaimoğlu ve Doğru (2016), 300 ve 500 mM' lık tuz uygulamalarının iki mısır genotipinde kök ve gövdenin taze ve kuru ağırlıkları ile köklerdeki dehidrogenaz aktivitesini kontrole göre önemli oranda azalttığını belirlemiştir [9]. Tuz stresi altındaki bitkilerde biyokütle birikiminde gözlenen azalma çoğunlukla iyon dengesizliğine bağlanmaktadır. Tuz stresi bitkilerde generatif gelişme evresinde de etkili olmaktadır. Örneğin Khatun ve Flowers (1995) $10 \mathrm{mM}$ ' lık tuz uygulamasının pirinç bitkilerinde steril çiçek oluşumunu artırdığını, tohum oluşumunu ise \%38 oranında azalttı̆̆ını bildirmiştir [42].

\subsection{Fotosentetik Aktivite}

Biyokütle üretimi sonucunda meydana gelen büyüme, net fotosentezin bir ölçüsüdür ve büyümeyi etkileyen çevresel stres faktörleri fotosentezi de etkilemektedir. Bu nedenle stres altındaki bitkilerde fotosentetik aktivitede meydana gelen değişimler, bir anlamda bitkilerin genel sağlık durumu hakkında bilgi vermektedir. Fotosentetik aktivitede meydana gelen değişimler bitkilerde, alglerde ve siyanobakterlerde bir stres sensörü olarak kabul edilmektedir.

Bitkilerde, toprak tuzluluğu da dahil tüm stres faktörleri fotosentetik pigment miktarında, bu pigmentlerin 1 şık enerjisini absorblaması ile başlayan primer fotokimyasal olaylarda, tilakoid membranların ve üzerindeki birimlerin yapısal organizasyonunda, elektron taşınım ve $\mathrm{CO}_{2}$ fiksasyon reaksiyonlarının hızlarında değişimlere yol açmaktadır [43].

Elektron mikroskobu ile yapılan çalışmalar, tuz stresinin kloroplast yapısında bazı değişimlere neden olarak fotosentetik aktiviteyi azalttı̆ı̆ını göstermiştir. Örneğin tuz stresi uygulanan patates bitkisinin mezofil hücrelerinde kloroplastlardaki tilakoid membranların şiştiği, yüksek tuz konsantrasyonlarının ise tilakoidlerin tamamen parçalanmasına neden olduğu rapor edilmiştir [44]. Bruns ve Hecht-Buchholz (1990), tuz stresi altındaki patates bitkilerinde grana sayısının azaldığını, tilakoidlerin şiştiğini ve stromada daha büyük nişasta tanelerinin birikim gösterdiğini belirlemiştir [45]. Tuz stresi domates bitkisinde kloroplastların agregasyona uğramasına, hücresel membranların yapısal olarak bozulmasina, grana ve tilakoidlerin yok olmasına neden olmuştur [46].

Tuz stresi altındaki bitkilerde fotosentetik pigment miktarı genellikle azalmaktadır. Agastian ve arkadaşları (2000), tuz uygulamalarının yaşlı yapraklarda daha erken bir dönemde klorosise neden olduğunu ve stres süresinin uzamas durumunda bu yaprakların absisyona uğradığını rapor etmiş̧iir [47]. Ancak Wang ve Nil (2000), tuz stresi uygulanan Amaranthus bitkilerinin yapraklarında klorofil miktarının arttığını bildirmiştir [36]. Yapılan diğer bazı çalışmalarda da Greviela arenaria' da toplam klorofil ve protoklorofillit, domateste toplam klorofil ve klorofil a, Bruguiera parviflora' da klorofil a ve klorofil b, pirinçte ise toplam klorofil miktarının kontrol bitkilerine göre azaldığ belirlenmiştir [48, 46, 49]. Chutipaijit ve arkadaşları (2011), tuz stresi altındaki bitkilerde klorofil miktarında meydana gelen değişimlerin, hücresel metabolizma olayları için duyarlı bir indikator olarak kullanılabileceğini ileri sürmüştür [50]. Maxwell ve Johnson (2000) ise, tuz stresinin bitkiler üzerindeki en bariz etkilerinden birisinin fotosentetik pigment biyosentezindeki değişimler olduğunu ifade etmiştir [51].

Tuz stresi bitkileri kısa ve uzun bir süreçte farklı mekanizmalarla etkilemektedir. Kısa süreli etkiler, tuz uygulamasından sonra birkaç saat veya birkaç gün içinde ortaya çıkmaya başlamaktadır. $\mathrm{Bu}$ süreç stomaların kapanması sonucunda karbon asimilasyonunun yavaşlaması nedeniyle oldukça önemlidir. Tuzluluğun karbon asimilasyon hızını uzun vadede azaltmasının sebebi, tuz iyonlarının yapraklarda birikim göstermesi ile ortaya çıkan sodyum ve klor toksisitesidir [52]. Tuz stresi altında bitkilerdeki karbon asimilasyon hızında görülen değişimler farklılık gösterebilmektedir. Örneğin Alhagi pseudoalhagi' de karbon asimilasyon hizı $50 \mathrm{mM}$ ' lik tuz uygulamas sonucu artmış, $100 \mathrm{mM}$ ' lik tuz uygulaması sonucunda değişmemiş̧, $200 \mathrm{mM}$ ' lik tuz uygulaması sonucunda ise kontrole göre $\% 60$ oranında azalmıştır [39]. Benzer şekilde tuz stresi uygulanan bitkilerde stomaların iletkenlik derecesi ve yaprak dokularındaki $\mathrm{CO}_{2}$ konsantrasyonunun kontrol bitkilerine göre düşük olduğu belirlenmiştir [39]. Dut bitkisinde ise tuz stresi koşullarında net $\mathrm{CO}_{2}$ asimilasyon 
hızı, stoma iletkenlik derecesi ve transpirasyon hızının azaldığ 1 tespit edilmiştir [47]. Parida ve arkadaşları (2004) ise tuz stresinin $B$. parviflora bitkisinde düşük konsantrasyonlarda net $\mathrm{CO}_{2}$ asimilasyon hızını artırırken, yüksek konsantrasyonlarda azalttığını belirlemişlerdir [6]. Tuz stresi bitkilerde $\mathrm{CO}_{2}$ fiksasyon reaksiyonlarında rol oynayan enzimlerin aktiviteleri üzerinde de farklı etkilere sahiptir. Örneğin, Atriplex lentiformis bitkisinde tuz stresi ribuloz-1,5-bisfosfat karboksilaz/oksigenaz (Rubisco) enziminin aktivitesini etkilemezken, fosfoenolpürivat karboksilaz (PEPC) aktivitesini artırmıştır [53]. Salicornia brachiata' da da tuz stresinin Rubisco, ribuloz-5-fosfat kinaz, ribuloz-5-fosfat izomeraz ve NADP-gliseraldehit-3fosfat dehidrogenaz aktivitelerini inhibe ettiği belirlenmiştir [54].

\subsection{Bitki-ortam-su İlişkisi}

Bitki dokularındaki su miktarını düzenleyen mekanizma suyun alınımı ve kaybedilmesi ile ilgilidir. Tuz stresi altındaki bitkilerin dokularındaki su miktarı türe ve aynı türün genotiplerine bağlı olarak değişebilmektedir. Tuzlu koşullarda dokularındaki su miktarı daha fazla olan bitkiler tuza daha toleranslı olarak kabul edilmektedir. Günümüzde yaprakların sahip olduğu su miktarının, bitkilerin genel su durumunun belirlenmesinde en güvenilir indikatör olduğu değerlendirilmektedir. Bitkilerde uygulanan tuz konsantrasyonu arttıkça su potansiyeli ve ozmotik potansiyelin daha negatif değerlere sahip olduğu, turgor basıncının ise arttığı belirlenmiştir [55, 41, 17, 56, 57]. Bazı araştırıcılar tuza duyarlı olan bitki türlerinin ve genotiplerinin yapraklarında daha yüksek turgor basıncının bulunduğunu ileri sürmüştür [58, 10]. Aziz ve Khan (2001) artan tuz konsantrasyonlarına bağlı olarak Rhizophora mucronata' da yaprakların su ve ozmotik potansiyeli ile ksilem geriliminin arttığını rapor etmiştir [17]. Benzer şekilde Chrysanthemum' a uygulanan yüksek tuz konsantrasyonları yaprakların ozmotik potansiyelini azaltmıştır [59]. Hint keneviri bitkisinde de kısa süreli tuz stresi uygulamaları oransal su miktarı, transpirasyon hızı, yaprak su potansiyeli, su alınımı ve suyun kullanım etkinliğini azaltmıştır [60]. Halofit bir bitki olan Urochondra setulosa' da yüksek tuz konsantrasyonlarında su potansiyeli, ozmotik potansiyel ve stoma iletkenlik derecesi daha negative değerlere ulaşırken; basınç potansiyeli azalmıştır [61]. Yine halofit bir bitki olan Suaeda salsa' da ise tuz stresi yaprakların su potansiyelini ve evaporasyon hızını azaltırken, yaprakların oransal su miktarında değişime neden olmamıştır [62]. Doğru (2014) ise tuz stresi altındaki iki misır genotipinin yapraklarında oransal su miktarının azaldığını, su eksiklik indeksinin ise arttığını bildirmiştir [8].

\section{4. Çözünür Karbohidratlar}

Yapılan araştırmalar, diğer organik bileşiklerle karşılaştırıldığında, şekerlerin tuz stresi altındaki glikofitlerde ozmotik potansiyelin düzenlenmesi konusunda yaklaşık \%50' lik bir paya sahip olduğunu göstermiştir [63]. Bitkilerde net $\mathrm{CO}_{2}$ asimilasyonundaki azalmaya rağmen, tuz ve kuraklık stresi sonucu çözünür karbohidratların birikim gösterdiği belirlenmiştir [11]. Yapılan bazı çalışmalarda da tuz toleransı ile çözünür karbohidrat birikiminin boyutu arasındaki ilişki ortaya konulmuştur. Ashraf ve Tufail (1995) tuz toleransı bakımından farklılık gösteren 5 ayçiçeği genotipinde çözünür şeker miktarını araştırmışlar, tüm genotiplerde çözünür şeker miktarının arttığını ancak tuza toleranslı olan genotipde bu birikimin daha belirgin olduğunu belirlemişlerdir [64]. Aspirde ise tuz stresi uygulamaları sonucunda tuz toleransının çözünür şeker birikimi ile korelasyon göstermediği ortaya çıkarılmıştır [65].

Bir disakkarit olan trehaloz adlı karbohidratın birçok organizmada çeşitli stres faktörlerinin etkisiyle sentezlendiği belirlenmiştir [66] (Şekil 3). Trehalozun su kaybına yol açan stres faktörlerine maruz kalan bitki hücrelerinde membran ve proteinlerin korunmasını sağladığı [67] ve denatüre olmuş proteinlerin agregasyonunu azalttığı bilinmektedir [68]. Yamada ve arkadaşları (2003) trehalozun apoptotik hücre ölümlerini baskıladığını bildirmiştir [69]. Trehalozun önemli tarımsal bitkileri de içeren birçok vasküler bitki dokusunda eser miktarda bulunduğu bilinmektedir. Tuz stresi altındaki yulaf kök ve nodüllerinde trehaloz birikiminin çok düşük konsantrasyonlarda gerçekleşmesi, bu şekerin ozmoregülasyondaki rolünün küçük olduğunu göstermektedir [70]. Escherichia coli' nin trehaloz biyosentetik genlerinin (otsA and otsB) pirinç bitkisinde önemli oranda ekspreslendiği de ortaya çıkarılmıştır [71]. Benzer şekilde transgenik tiplerde tuz, kuraklık ve düşük sıcaklık stresi koşullarında büyümenin devam ettiği, fotooksidatif hasarın daha az olduğu ve mineral dengesinin daha sağlıklı bir şekilde sağlandığı gözlenmiştir. Transgenik pirinç bitkilerindeki trehaloz birikimi, transgenik olmayanlara göre 3-10 kat daha fazladır. E. coli' nin trehaloz-6-fosfat sentaz ve trehaloz-6-fosfat fosfataz genlerine sahip olan pirinç bitkilerinde de trehaloz birikiminin ve bazı abiyotik stres faktörlerine tolerans derecesinin arttığı görülmüştür [72]. Trehalozun tuz toleransındaki fonksiyonunun anlaşılabilmesi için daha fazla sayıda bitki türünde araştırmaların yapılması gerekmektedir.

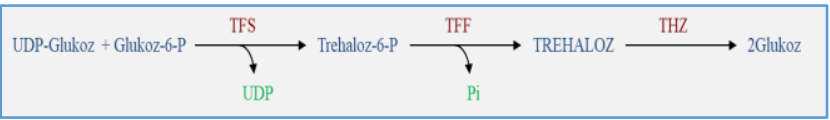

Şekil 3. Bitki hücrelerinde trehaloz metabolizması (TFS: Trehaloz fosfat sentetaz; TFF: Trehaloz fosfat fosfataz; THZ: Trehalaz; UDP: Uridin difosfat; Pi: İnorganik fosfat) [66].

Tuz stresine cevap olarak çözünür şekerlerin birikiminde görülen önemli varyasyonlar, tuza tolerant olan birçok tür ve genotipte gözlenmiştir. Sonuç olarak şekerlerin bitkilerde tuz toleransının sağlanması ile ilgili rolleri belli oranda tartışmalıdır. Ancak çözünür şekerlerin tuz toleransı konusunda potansiyel birer indikatör oldukları olasılığı göz ardi edilmemelidir. 


\section{5. Çözünür Proteinler}

Bitkilerde tuz stresi ile indüklenen birçok protein tanımlanmıştır [73]. Bitkilerde tuz stresi altında sentezlenen proteinler, stres koşulları ortadan kalktıktan sonra kullanılmak üzere azotun depolanmasını sağladı̆̆ ozmotik regülasyona da katkıda bulunur [74]. Bu tip proteinler tuz stresinin başlamasından sonra de novo olarak sentezlenebileceği gibi, dokularda düşük konsantrasyonlarda bulunurken stresle birlikte miktarları artabilir [75]. Tuz stresi ile indüklenen proteinlere örnek olarak tütünde tanımlanan $26 \mathrm{kDa}$ ' lik ozmotin verilebilir [74]. Tuz stresine maruz bırakılan Mesembryanthemum crystallinum' da da ozmotin benzeri bir protein belirlenmiştir [76]. Arpada ise immünolojik olarak ozmotinle ilgili olmayan ve germin adı verilen iki tane $26 \mathrm{kDa}$ ' lik proteinin tuz stresine cevap olarak sentezlendiği gözlenmiştir [77]. LEA (late embryogenesis abundant) proteinlerinden iki tanesini (PMA80 ve PMA1959) içeren transgenik pirinç bitkilerinde, ikinci generasyona ait bireylerin dokularında kuraklık ve tuz stresi uygulamaları sonucunda hem bu iki protein miktarının hem de iki stres faktörüne toleransın arttı̆̆ gözlenmiştir [78]. Bruguiera sexangula' da tuz toleransinın artmasina neden olan spesifik bir protein (allen oksid siklaz) tanımlanmış ve bu proteinin ekspreslendiği Saccharomyces cerevisiae ve tütünde tuz toleransının arttığı anlaşılmıştır [79].

Tuz stresine toleranslı olan arpa [80], ayçiçeği [64], darı [81] ve pirinç [75] bitkilerinde de toleranslı olmayanlara göre çözünür protein miktarının daha yüksek olduğu ortaya çıkarılmıştır. Buğdayda yapılan bir çalışmada ise tuz stresi altında duyarlı olan genotiplerin dokularındaki çözünür protein birikiminin daha belirgin olduğu gösterilmiştir [82] Tuz stresi uygulanan iki buğday genotipinin dokularındaki polipeptid profilinde meydana gelen değişimlerin sadece kantitatif olduğu, 29 ve 48 kDa' lik iki proteinin dokulardaki miktarının azaldığı belirlenmiştir. Ancak protein profilinde meydana gelen kantitatif değişimler tuz stresi koşullarında bazı metabolik mekanizmaların düzenlenmesinden sorumlu olabilir [83].

Su mercimeğinde ise tuz stresinin tuz toleransından bağımsız olarak yapraklardaki çözünür protein miktarını azalttığ gözlenmiştir [84]. Benzer şekilde aspir [65] ve Eruca sativa' da [85] yapraklardaki çözünür protein miktarı, tuza toleranslı olan ve olmayan genotiplerde farklılık göstermemiştir. Pareek ve arkadaşları (1997) stres proteinlerinin tuz toleransının geliştirilmesi konusunda önemli moleküler indikatörler olduğunu ileri sürmüşlerdir [75]. Ancak yukarıda bahsedilen araştırma sonuçları, bunun bitki türüne ve genotipine bağlı olarak değişebileceğini göstermektedir.

\subsection{Aminoasitler}

Alanin, arjinin, glisin, prolin, serin, lösin, valin, glutamin ve asparagin gibi proteinik aminoasitlerin yanı sıra; sitrüllin ve ornitin gibi proteinik olmayan aminoasitlerin tuz stresi altındaki bitki dokularında belli oranda birikim gösterdiği bilinmektedir [13, 86, 87]. Ayçiçeği [64], aspir [65], Eruca sativa [85], ve Lens culinaris' in [77] tuza toleranslı olan genotiplerinin yapraklarındaki toplam serbest amino asit miktarı, duyarlı olanlara göre daha fazla bulunmuştur.

Tuz stresi altındaki gelişmiş bitkilerde prolin birikimi, diğer amino asitlerle karşılaştırıldığında daha fazladır [88] (Şekil 4).

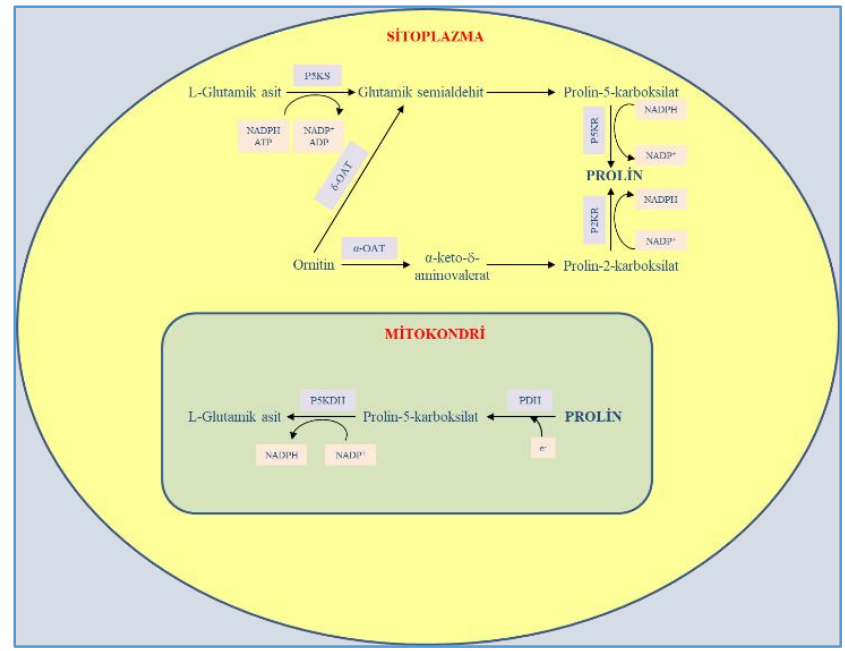

Şekil 4. Gelişmiş bitkilerde prolin metabolizması (P5KS: Prolin-5-karboksilat sentetaz; P5KR: Prolin-5-karboksilat redüktaz; P2KR: Prolin-2-karboksilat redüktaz; $\alpha$-OAT: Ornitin- $\alpha$-aminotransferaz; $\delta$-OAT: $\quad$ Ornitin- $\delta$ aminotransferaz; PDH: Prolin dehidrogenaz; P5KDH: Prolin-5-karboksilat dehidrogenaz) [88].

Tuz stresi altındaki birçok monokotil bitki türünde prolin birikimi yaygın olarak görülen bir olaydır [89]. Ancak yapılan bir çalışmada tuz stresinin arpada prolin birikimine neden olmadığı anlaşılmıştır [90]. Bitki dokularındaki prolin birikimi kuraklık stresi sonucu da görülebilir. Bu durumda prolin sentezi düşük su potansiyeline verilen ancak spesifik olmayan bir cevap olarak değerlendirilebilir [85]. Prolin ozmotik olarak aktif bir bileşiktir ve bitki hücrelerinde kullanılabilir azot birikiminin regülasyonundan sorumludur [85]. Ayrıca tuz stresinin hücre membranları üzerindeki olumsuz etkisini azaltarak membran stabilitesinin sağlanmasında da etkilidir [91]. Prolinin diğer önemli bir özelliği de yüksek konsantrasyonlarda bile enzim aktivitesi üzerinde inhibisyon etkisine sahip olmamasıdır [87]. Bazı araştırıcılar da prolinin adaptasyon sürecinin bir bileşeni olduğunu ve çoklu cevapların aktivasyonu için gerekli düzenleyici mekanizmalarda rol oynayabileceğini ileri sürmüş̧ür [92]. Ancak prolinin ozmoregülasyon ve tuz toleransı konusundaki fonksiyonu kısmen tartışmalıdır. Lutts ve arkadaşları (1996) tuz stresi altındaki pirinç bitkilerinde prolinin ozmotik regülasyonda rol oynamadığı ve prolin birikiminin tuz toleransı için bir indikatör olmaktan çok bir hasar semptomu olduğunu belirlemişlerdir [92]. Yapılan bir çalışmada da prolin birikiminin tuz stresine maruz kalan buğdayda önemli bir fonksiyona sahip olmadığı ortaya çıkarılmıştır [93]. Tuzlu koşullarda kültüre alınmış arpa embriyolarında ise dışarıdan yapılan prolin uygulamaları 
gövdelerdeki $\mathrm{Na}^{+}$ve $\mathrm{Cl}^{-}$birikimini azaltmış ve büyüme üzerinde olumlu etkiler yaratmıştır [94]. Dışarıdan verilen prolinin pirinçte tuz stresinin olumsuz etkilerini azalttığına dair sonuçlar da elde edilmiştir [95].

Bunun gibi çelişkilere rağmen prolin konsantrasyonunun tuza toleranslı olan birçok bitki türünde, duyarlı olanlara göre daha yüksek olduğu belirlenmiștir. Ahmad ve arkadaşları (1981) da tuza toleranslı olan Agrostis stolonifera ekotiplerinde tuz stresine cevap olarak, duyarlı ekotiplere göre daha fazla prolin birikimi olduğunu bulmuşlardır [96]. Nispeten tuza toleranslı olan Brassica juncea bitkilerinin yapraklarında ozmotik regülasyon yeteneğinin, kritik tuz konsantrasyonunun ve serbest prolin miktarının daha yüksek olduğu belirlenmiştir [97]. Tuza toleranslı olan B. juncea' da kontrol bitkilerine göre, tuzlu koşullarda yüksek prolin konsantrasyonu ve daha iyi büyüme görülmüştür [98]. Madan ve arkadaşları (1995) ise tuz stresi koşullarında toleranslı genotiplerdeki prolin-5-karboksilat redüktaz ve ornitin aminotransferaz gibi prolin biyosentezi ile ilgili enzimlerin aktivitelerinde önemli derecede artışlar belirlemiştir. Ancak prolin oksidaz gibi prolin parçalayan enzimlerin aktiviteleri ise azalmıştır [99].

Ancak bazı çalışmalar da tuza duyarlı genotiplerdeki prolin birikiminin toleranslı olanlara göre daha fazla olduğunu ortaya çıkarmıştır. Moftah ve Michel (1987) tuz stresi altındaki soya fasülyesinde, prolin miktarının bir indikatör olarak kullanılamayacağını bildirmiştir [100]. Benzer şekilde Ashraf (1989) da Vigna mungo' da prolin birikimi ile tuz toleransı arasında negatif bir korelasyonun varlığını ortaya çıkarmıştır [101]. Pirinçte de tuza dayanıklı genotiplerin (Nona Bokra ve IR4630), duyarlı genotiplere (Kong Pao ve IR31785) göre daha az prolin birikimi gösterdiği rapor edilmiştir [92]. Bu konudaki çelişkili sonuçlardan dolayı, prolin miktarındaki değişimlerin tuz stresi bakımından bir tolerans ve seleksiyon kriteri olarak kullanılıp kullanılamayacağı konusunda araştırıcılar arasında fikir birliği yoktur.

\subsection{Kuaterner Amonyum Bileşikleri}

Tuz stresine maruz kalan bitkilerde ozmoregülatör olarak fonksiyon yapan kuaterner amonyum bileşikleri arasında glisinbetain, $\beta$-alaninbetain, prolinbetain, kolin-o-sülfat, hidroksiprolinbetain ve pipekolatbetain sayllabilir [13]. Birçok bitki türünde yaprak ozmotik potansiyeli ile glisinbetain, $\beta$-alaninbetain ve prolinbetain miktarı arasında pozitif bir korelasyon görülmüştür [102]. Bu organik bileşiklerin aynı zamanda hücrelerde ozmotik olarak koruyucu etkilere sahip olduğu da bilinmektedir [103]. Tuz stresine maruz kalan bitkilerdeki kuaterner amonyum bileşikleri içinde en fazla bulunanı glisinbetaindir [13] (Şekil 5). Glisinbetainin 1spanak, arpa, domates, patates, pirinç, havuç ve sorgum gibi birçok tarımsal bitki türünün dokularında strese cevap olarak birikim gösterdiği belirlenmiştir [104, 105]. Bu organik bileşikler büyük ölçüde kloroplastlarda bulunmakta ve tilakoid membranları koruyarak tuz stresi altında fotosentetik aktivitenin sürekliliğini sağlamaktadır [106]. Murata ve arkadaşları (1992) glisinbetainin, tuz stresi koşullarında fotosistem II' nin kompleks ekstrinsik proteinlerinin organizasyonunu stabilize ederek fotosistem II' yi koruduğunu belirlemişlerdir [107].

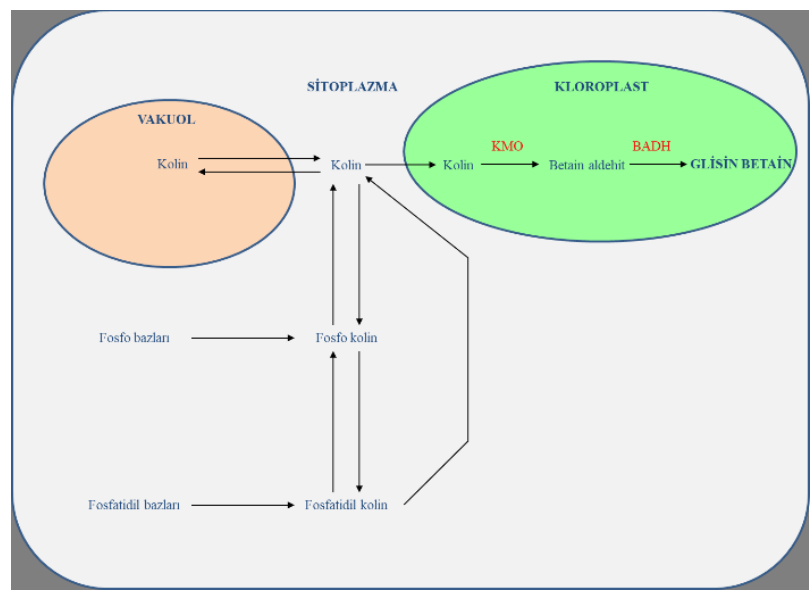

Şekil 5. Gelişmiş bitkilerde glisinbetain sentezi (KMO: Kolin monooksigenaz; BADH: Betain aldehit dehidrogenaz [13].

Tuz stresi altındaki çimlerde glisinbetain birikiminin toleranslı genotiplerde duyarlı olanlara göre daha fazla olduğu ortaya çıkarılmıştır [108]. Saneoka ve arkadaşları (1995) misirın glisinbetain biriktiren genotiplerinde tuzlu koşullar altında gövde büyümesindeki inhibisyonun daha az olduğunu göstermişlerdir [109]. Buğdayın tuza toleranslı genotiplerinin genç yapraklarındaki glisinbetain miktarı ile tolerans derecesi arasinda da pozitif bir korelasyon belirlenmiştir [93]. Bunun yanı sıra, glisinbetain sentezinden sorumlu betain aldehit dehidrogenaz enziminin aktivitesinin birçok bitki türünde tuz stresi altında arttığı ortaya çıkarılmışıır [110]. Ancak Trifolium alexandrinum' da tuz stresi uygulamalarının kolin ve betain birikiminin tuza duyarlı genotiplerde daha belirgin olduğu anlaşılmıştır [111]. $\mathrm{Bu}$ sonuçlar, tuz stresi altındaki bitkilerdeki glisinbetain birikiminin türe bağlı olarak varyasyon gösterdiğini kanıtlamaktadır.

\subsection{Polioller}

Polioller ozmotik etkinliğe sahip bileşikler olduğundan, bitkilerdeki ozmoregülasyon mekanizması ve dolayısıyla tuz toleransı konusunda da etkili oldukları düşünülmektedir [112]. Kimyasal olarak değerlendirildiğinde polioller polihidrik alkollerdir. Bitkiler aleminde oldukça geniş bir yayılım gösteren siklik ve asiklik yapıya sahip birçok poliol mevcuttur [113] (Şekil 6). Bitkisel dokularda en fazla rastlanan asiklik polioller; mannitol, gliserol ve sorbitoldür. Siklik poliollerden de en fazla ononitol ve pinitol bulunur. Genellikle polioller birçok halofit bitkinin sitoplazmasında ve vakuolünde, yüksek konsantrasyonda birikim gösteren inorganik iyonların neden olduğu ozmotik bozuklukların ortadan kaldırılması için biriktirilir [114]. Poliollerin ozmotik regülasyon dışında etkili birer oksijen radikali temizleyicisi oldukları da bilinmektedir. Örneğin mannitolün 
in vitro koşullarda reaktif oksijen türlerini detoksifiye ettiği [115] ve kuraklık stresi altındaki bitkilerde proteinleri oksidatif hasara karşı koruduğu belirlenmiştir [116]. Smirnoff and Cumbes (1989) de mannitol, sorbitol, gliserol, ononitol and pinitolün etkili birer radikal temizleyicisi olduklarını rapor etmiştir [117].

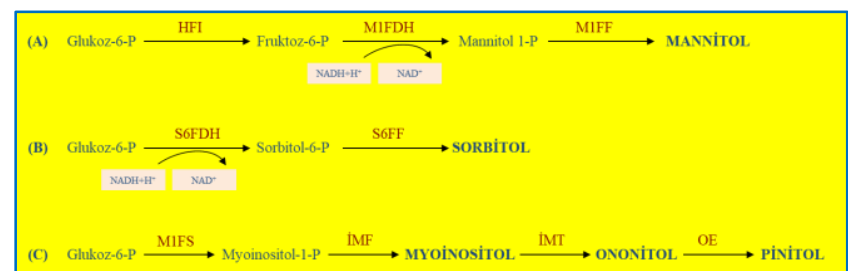

Şekil 6. Gelişmiş bitkilerde (A) mannitol, (B) sorbitol ve (C) myoinositol biyosentez reaksiyonları (HFI: Heksoz fosfat izomeraz; M1FDH: Mannitol-1-fosfat dehidrogenaz; M1FF: Mannitol-1-fosfat fosfataz; S6FDH: Sorbitol-6-fosfat dehidrogenaz; S6FF: Sorbitol-6-fosfat fosfataz; M1FS: Myoinositol-1-fosfat sentetaz; İMF: İnositol monofosfataz; IMT: İnositol metiltransferaz; OE: Ornitin epimeraz [113].

Birçok bitki türünde kuraklık ve tuz stresine cevap olarak poliollerin birikim gösterdiği belirtilmiştir [15]. Mannitolün bitkilerde yüksek tuz konsantrasyonlarını tolere etme yeteneğini artırdığı gösterilmiştir. Örneğin normal koşullarda mannitol sentezlemeyen ve biriktirmeyen tütün bitkisine bakteriyel mannitol-1-fosfat dehidrogenaz ( $m$ tID) geni verilmiş ve oluşturulan transgenik tütün bitkisi yaprak ve köklerinde mannitol birikimi yaparak tuza tolerans kazanmıştır [118]. Benzer şekilde aynı bakteriyel gen verilerek oluşturulan transgenik buğday bitkileri de yapraklarında mannitol biriktirerek hem kuraklık hem de tuz stresi altında yüksek büyüme hızı sergilemiştir [15]. Bu sonuçlar bitki dokularındaki mannitol birikimi ile tuz toleransı arasında pozitif bir ilişki olduğunu göstermektedir.

Pinitol ve diğer bazı o-metil inositollerin birçok baklagil türünde bulunduğu ve $\mathrm{D}$-pinitolün serbest radikallerin detoksifikasyonu dışında vakuol ve sitoplazma arasındaki ozmotik regülasyon konusunda önemli bir rol oynadığı belirlenmiştir [119]. Pinitolün aynı zamanda tuz stresine maruz birakılan Honkenya peploides ve Sesbania aculeata bitkilerinde de birikim gösterdiği rapor edilmiştir [120, 121]. Yonca bitkilerinde gözlenen pinitol ve ononitol birikimi, bu bileşiklerin tuz toleransının kazanılmasında etkili olabileceğini göstermektedir [70]. Poliollerin tuz stresi altındaki bitkilerdeki fizyolojik fonksiyonları hakkındaki bilgiler oldukça sınırlıdır. Ancak son yıllarda poliol birikiminin biyokimyasal ve genetik esasları ile ilgili önemli gelişmeler kaydedilmiştir.

Halofit bir bitki olan Mesembryanthemum crystallinum' da tuz stresi etkisiyle miyoinositol-o-metil transferaz enzimini kodlayan genin ekspresyonunun arttığı gözlenmiştir [122]. Bunun yanı sira, aynı türde tuz stresinin floemdeki miyoinositolün, $\mathrm{Na}^{+}$ile inositolün yapraklara karşılıklı taşınımlarını artırdığ $1 ; \mathrm{Na}^{+}$alınımı ile miyoinositolün bitki içindeki dağılımındaki değişimler arasında bir etkileşimin bulunduğu belirlenmiştir [114]. Bu sonuç aynı zamanda miyoinositolün ozmotik etkinliğe sahip olan bileşiklerin sentezi için substrat olarak görev yapmasının yanı sıra, $\mathrm{Na}^{+}$ alınımını sağlayan ve yapraklardan köklere gönderilen bir sinyal olarak da önemli olduğunu göstermiştir. Sheveleva ve arkadaşları (1997) ise miyoinositol-o-metil transferaz enzimi bakımından oluşturdukları transgenik tütün bitkilerinin kuraklık veya tuz stresine maruz kaldıklarında yüksek miktarda D-ononitol biriktirdiğini belirtmişlerdir [123]. Bu sonuçlar genetik olarak değiştirilmiş bitki türlerinde gerçekleşen poliol birikiminin belli oranda tuz toleransı sağladığını göstermektedir. Poliol birikimi ile tuz toleransı arasındaki korelasyonun net şekilde ortaya çıkarılması, bu bileşiklerin 1slah programlarında indikatör olarak kullanılmasını da sağlayacaktır.

\subsection{Lipidler}

Lipidler bitki hücrelerindeki önemli enerji kaynakları olmalarının yanı sıra hücresel membran sistemleri için vazgeçilmez yapısal birimlerdir [124]. Lipidler aynı zamanda birçok çevresel stres faktörüne karşı tolerans geliştirilmesi konusunda da önemli rol oynamaktadır. Örneğin aşırı kuraklığa karşı toleransın oluşabilmesi, stres koşulları altında iki katlı fosfolipid tabakasının karbohidratlarla, özellikle de trehaloz ile stabilizasyonuna bağlıdır. Yağ asitlerinin doymamış hale geçmesi tuz ve kuraklık stresi altındaki bitkilerde koruma sağlamaktadır. Olefinik bağlara yakın konumda bulunan hidrojen atomları oksidatif saldırılara oldukça duyarlıdır. Lipidler, yapılarında bu bağlardan bol miktarda bulundurduğu için, oksidatif reaksiyonlar için primer hedef konumunda olan moleküllerdir. Eğer ilgili enzimler oksidatif reaksiyonları kontrol altında tutamazsa, lipidlerin oksidasyonu bazı ürünlerin oluşmasına yol açmakta ve bu ürünler de protein ve DNA moleküllerinde yapısal hasarlara neden olmaktadır [124]. Arachis hypogea bitkisinde 45 mM' a kadar olan tuz uygulamalarının lipid miktarını artırdığı, daha yüksek tuz konsantrasyonlarının ise azalttığı belirlenmiştir [125]. Wu ve arkadaşları (1998), tuz stresi altındaki Spartina patens bitkisinin kök hücre membranlarındaki lipid kompozisyonundaki değişimleri araştırmış; artan tuz konsantrasyonları sonucunda sterol ve fosfolipid miktarının azaldığını, sterol/fosfolipid oranının ise değişmediğini gözlemlemişlerdir [126]. Bunun yanı sıra aynı çalışmada, tuz stresinin glikolipid miktarını artırdığı, fosfatidilkolin ve fosfatidiletanolamin miktarını azalttı̆̆ belirlenmiştir. Yapılan diğer bir çalışmada ise, 100 mM' lık tuz stresine toleranslı olan domates bitkisinin kalluslarından izole edilen membran vesiküllerinin yapısındaki fosfolipid ve sterol miktarının kontrole göre artış gösterdiği, fosfolipid/serbest sterol oranının ve fosfolipidlerin yapısına giren yağ asitlerindeki çift bağ indeksinin azaldığı rapor edilmiştir [16]. Bu sonuçlar tuz stresinin, hücresel mebranların lipid kompozisyonunu ve dolayısıyla seçici geçirgenlik özelliğini belirli oranda değiştirdiğini göstermektedir. 


\section{qq3.10. Mineral Madde Beslenmesi}

Toprağın yapısında bulunan yüksek konsantrasyondaki tuz, özellikle $\mathrm{K}^{+}$gibi mineral maddelerle rekabete girerek, bunun bitki kök hücrelerine alınımını inhibe edebilir. Sonuçta bitkide $\mathrm{K}^{+}$eksikliği ortaya çıkar. Yüksek tuz konsantrasyonları birçok bitki türünde dokulardaki $\mathrm{Na}^{+}$ve $\mathrm{Cl}^{-}$miktarını artırırken; $\mathrm{K}^{+}, \mathrm{Ca}^{+2}$ ve $\mathrm{Mg}^{+2}$ miktarını azaltmaktadır [17]. Vicia faba ile yapılan bir çalışmada tuz stresinin $\mathrm{Na}^{+}, \mathrm{Ca}^{+2}$ ve $\mathrm{Cl}^{-}$miktarını artırdığı; $\mathrm{K}^{+} / \mathrm{Na}^{+}$oranını ise azalttı̆ğ belirlenmiştir [91]. A. pseudoalhagi' de 200 mM' lik tuz uygulamalarının yapraklardaki $\mathrm{Na}^{+}$miktarını kontrole göre 45 kat artırdığı, ancak bitkilerin bu kadar yüksek $\mathrm{Na}^{+}$konsantrasyonunda bile büyümeye devam ettikleri rapor edilmiştir [39]. Tropikal bir bitki olan guavada tuz uygulamaları köklerle karşılaştırıldı̆̆ında özellikle yapraklarda çok daha belirgin şekilde $\mathrm{Na}^{+}$ve $\mathrm{Cl}^{-}$birikimine neden olmuştur. Aynı çalışmada köklerdeki $\mathrm{Ca}^{+2}$ miktarının değiş̧mediği ancak yapraklarda $\mathrm{Ca}^{+2}, \mathrm{Mg}^{+2}$ ve $\mathrm{K}^{+}$birikiminin azaldığı tespit edilmiştir [127]. Parida ve arkadaşları (2004) Bruguiera parviflora' da tuz stresinin yapraklardaki $\mathrm{Na}^{+}$ve $\mathrm{Cl}^{-}$miktarını artırdığını, $\mathrm{K}^{+}$ve $\mathrm{Fe}^{+2}$ miktarını etkilemediğini, $\mathrm{Ca}^{+2}$ ve $\mathrm{Mg}^{+2}$ miktarını ise azalttığını bildirmişlerdir [6]. Tuz stresinin mineral madde beslenmesi üzerindeki bu tip etkileri, büyümenin yavaşlamasının olası nedenleri arasında sayılmaktadır.

\subsection{Fitohormonlar}

Bitki hormonları bitkilerdeki stres cevaplarının indüksiyonu ile ilgili olan sinyal bileşiklerinin aktif üyeleridir [128]. Abiyotik stres faktörleri bitkilerde büyümenin yavaşlamasının yanı sıra dokulardaki fitohormon miktarlarında da değişikliklere neden olur [129].

İndol-3-asetik asit (IAA) bitki büyümesinin kontrolü üzerinde önemli bir role sahiptir. IAA özellikle hücre büyümesi, vasküler dokunun gelişimi ve apikal dominansi gibi olaylar üzerinde etkilidir [130]. Tuz stresi altındaki tarımsal bitkilerde IAA' nın bir cevap mekanizmasına sahip olduğu anlaşılmıştır. Ancak bitkilerde tuz stresi ile oksin miktarı arasındaki ilişkiye dair bilgiler sınırlıdır. Bu nedenle eksojen hormon uygulamaları sonucu ortaya çıkan stres cevaplarının incelenmesi gereklidir. Prakash ve Prathapasenan (1990), tuz stresinin pirinç yapraklarındaki IAA konsantrasyonunu önemli oranda azalttığını, $\mathrm{GA}_{3}$ ' ün dışarıdan uygulanması ile tuz stresinin sebep olduğu IAA miktarındaki azalmanın kısmen engellendiğini bildirmişlerdir [131]. Bu sonuçlar da tuz stresinin bitkilerde hormonal dengeyi ve bitki büyümesini etkilediğini göstermektedir.

Giberellik asit (GA) biyotik [132] veya abiyotik [133] stres faktörlerine maruz kalan bitki dokularında birikim gösterebilir. Bitkilerde tuz stresinin olumsuz etkilerini azaltmak amaciyla birçok farklı fitohormon kullanılmaktadır. Giberellinler bu konuda birçok araştırıcının özellikle üzerinde yoğunlaştı̆̆ bir fitohormondur. Örneğin GA' nın tuz stresi altındaki buğday ve pirinç bitkilerinde büyümeyi sağladığı rapor edilmiştir [131]. Tuz stresi koşullarında buğday tohumlarının çimlenme oranı, bitkilerin büyüme hızı ve tane veriminde meydana gelen azalmanın, $\mathrm{GA}_{3}$ uygulamaları ile arttığ1 gözlenmiştir. [134]. Diğer bir çalışmada da 20 ppm' lik $\mathrm{GA}_{3}$ ile muamele edilen buğday tohumlarının çimlenme oranının yükseldiği belirlenmiştir [135]. Bunun dışında GA' nın serbest radikallerin neden olduğu lipid peroksidasyonunu engellediği ortaya çıkarılmıştır [136]. Bu sonuçlar $\mathrm{GA}_{3}$ uygulamalarının tarımsal bitkilerde tuz toleransını artırabileceğini göstermektedir.

Sitokininlerin (SK) hücre bölünmesi, apikal dominansi, besin mobilizasyonu, kloroplast gelişimi, senesens ve çiçeklenme gibi birçok olay üzerinde düzenleyici rol oynadığı bilinmektedir [13]. SK' ler, hücre membranlarının mono ve divalent iyonlara karşı geçirgenliğini ve metabolik havuzları etkileyerek senesens olayını geciktirmektedir [137]. SK' ler özellikle tohum çimlenmesi, stoma hareketleri ve kotiledon genişlemesi gibi olaylar üzerinde $A B A$ ile tam ters etkilere neden olduklarından $\mathrm{ABA}$ antagonistleri olarak bilinir [138]. Uygun olmayan çevresel koşullar altında bitki dokularındaki SK miktarı genellikle azalma eğilimindedir. $\mathrm{Bu}$ durumda stres boyunca kökten sağlanan SK miktarındaki azalmanın, gövdedeki gen ekspresyonunu değiştirdiği ve sonuçta stresin olumsuz etkilerini düzeltecek uygun cevapları oluşturduğu düşünülmektedir [13].

SK grubundan bir hormon olan kinetinin domates, arpa ve pamuk tohumlarında stres etkisiyle oluşan dormansiyi kırdığı belirlenmiştir [139]. Stres koşulları altında endojen SK miktarında meydana gelen azalmanın sinırlayıcı bir faktör olduğu ve dışarıdan uygulanan kinetinin büyümeyi artırıcı bir etkiye sahip olduğu bilinmektedir [140]. Dışarıdan uygulanan kinetin buğday fidelerinde tuz stresinin neden olduğu olumsuz etkileri ortadan kaldırmış [141], patates fidelerine tuz stresi uygulamasindan hemen önce verilen kinetin benzer şekilde tuz stresinin büyümeyi inhibe edici etkisini azaltmıştır [142]. Fasülye bitkilerinde ise tuz stresi boyunca gerçekleştirilen kinetin uygulamaları tuz stresinin olumsuz etkilerini daha da artırmıştır [143]. Benzil adenin uygulamas tuza duyarlı olan arpa genotipinde büyümeyi inhibe ederken, toleranslı genotipte ise büyüme hızını ve internal SK miktarını artırmıştır [144]. Ayrıca kinetinin doğrudan doğruya bir serbest radikal temizleyicisi olduğu ve pürin parçalanmasını engelleme konusunda antioksidant savunma mekanizmasının bir bileşeni olduğu da belirlenmiştir [20].

Tuz stresinin bitkilerdeki absisik asit (ABA) sentezi üzerindeki etkileri ile ilgili birçok çalışma yapılmıştır. Tuz stresi altındaki Brassica [145], Phaseolus [146] ve Zea mays [21] bitkilerinin yaprak dokularındaki endojen ABA konsantrasyonu ile büyüme inhibisyonu arasında bir korelasyonun varlığı ortaya çıkarılmıştır. Bunun dışında ABA miktarının, büyümeye devam etmelerine rağmen, köklerde de artış gösterdiği [145] ve bunun da kök dokularının endojen veya eksojen ABA konsantrasyonlarına duyarlılığının farklı olmasından kaynaklanabileceği 
bildirilmiştir [147]. Bu sonuçlar kök ve gövde dokularının strese verdikleri cevabin, artan hormon konsantrasyonu ve hormonların ksilem öz suyu ile hareket ederek kök ve gövde arasında sağladığı iletişim ile koordine edildiğini göstermektedir [148].

Jeschke ve arkadaşları (1997), ksilemdeki artan ABA konsantrasyonu ile yaprak büyümesinin inhibisyonu arasında bir ilişki olduğunu ve tuz stresinin olgun Ricinus yapraklarındaki ABA miktarını artırdığını belirlemişlerdir [149]. Tuz stresi sonucunda köklerdeki ABA sentez hızının ve ABA' nın ksilemle taşınım hızının artması ile stoma cevapları arasında da bir korelasyon vardır. Bunun dişında köklerin doğrudan tuz stresine maruz kalması sonucu ABA' nın vakuollerdeki iyon birikimini stimüle ettiği ve bunun da tuz stresine adaptasyonu kolaylaştırdığı bilinmektedir [149]. Jae-Ung ve Youngsook (2001) ise stomaların kapanmasında rol oynayan ABA' nın kortikal aktin filamentlerinin hızla depolimerize olmasina ve yeni tip aktin filamentlerinin oluşmasına neden olduğunu, aktin organizasyonundaki bu değişimlerin de stoma kapanmasında etkili olan sinyal mekanizmasını aktive ettiğini bildirmiştir [150]. Montero ve arkadaşları (1997) tuz stresi etkisiyle sentezlenen ABA' nın yaprak büyümesinin inhibisyonunu regüle ettiğini ve yapraklardaki sodyum ve klor birikimini azalttığını ortaya çıkarmışlardır [151]. Sorgum bitkisinde ise ABA' nın tuz stresinin olumsuz etkilerini azalttığı ve iyonik strese toleransı artırdığı gözlenmiştir [152].

Jasmonatlar (JA) hem konakçı savunmasında hem de birçok fizyolojik olayda rol oynayan sinyal mekanizmalarının önemli bir bileşenidir [153]. Biyotik [132] veya abiyotik [133] stres faktörleri bitki dokularında JA birikimine neden olmaktadır. JA ve türevleri aynı zamanda tuz stresine verilen cevaplar konusunda da fonksiyoneldir [132]. Örneğin 200 mM' lık tuz uygulamaları pirinç köklerindeki jasmonik asit metil esterleri (JAME) miktarını önemli derecede artırmıştır [154]. Aynı zamanda arpa bitkilerine tuz stresinden önce uygulanan JA' nın büyüme ve fotosentetik aktiviteyi olumlu etkilediği belirlenmiştir [155]. JA miktarının toleranslı olan domates genotiplerinde tuz stresine cevap olarak artış gösterdiği, duyarlı genotiplerde ise azaldığı belirlenmiştir [128]. Sorbitol ve mannitolün kullanılmasıyla oluşturulan ozmotik stres durumunda arpa gövde segmentlerindeki JA miktarının arttığı ancak yüksek tuz konsantrasyonlarının herhangi bir artışa yol açmadığı belirlenmiştir [156]. Ancak tuz stresinin doğal bitki populasyonlarında endojen JA miktarını nasıl etkilediği bilinmemektedir.

Poliaminler iki veya daha fazla sayıda amino grubuna sahip olan polivalent bileşiklerdir. Gelişmiş bitkilerde en yaygın olarak bulunan poliaminler putressin, spermidin, spermin ve kadaverindir [13]. Bu bileşikler biyolojik rolleri esas alınarak iki grup altında incelenir [157]. Birinci grupta etkileri oksin ve giberellinlere benzerlik gösteren (hücre uzaması ve köklenme) putressin ve kadaverin bulunur [158]. İkinci grupta ise sitokininler gibi hücre bölünmesi, organogenesis ve senesens üzerinde etkili olan spermidin ve spermin bulunur [159]. Nötr $\mathrm{pH}$ değerlerinde poliaminler polikatyonlar gibi davranır ve hücrelerdeki DNA, RNA ve fosfolipidler gibi polianyonlara bağlanarak bu makromoleküllerin stabilizasyonunu sağlar. Bunun yanı sıra protoplastların stabilizasyonu, embriyogenesis boyunca hücre bölünmesinin aktivasyonu ve birçok bitki türünde senesensin geciktirilmesi gibi olaylarda etkilidir [106]. Diğer azotlu bileşiklerle karşılaştırıldığında poliaminlerin ozmotik regülasyon konusunda daha küçük bir fonksiyona sahip oldukları belirlenmiştir [160]. Ancak bezelye fidelerinde poliaminlerin tuz stresinin olumsuz etkilerini azalttığ 1 rapor edilmiştir [161].

Tuz stresi etkisiyle poliaminlerin dokulardaki birikimi konusunda bitki türlerine bağlı olarak farklılık görülmektedir. Poliaminlerin ve bunlarla ilgili önemli metabolik enzimlerin aktiviteleri stres altındaki Brassica campestris bitkisinde araştırılmıştır [162]. Buna göre kısa süreli stresin poliamin miktarı ile arjinin ve ornitin dekarboksilaz ve poliamin oksidaz aktivitesinde önemli değişimlere neden olduğu belirlenmiştir. Bazı araştırmalarda da poliaminlerin tuza toleranslı ve duyarlı olan bitki türlerindeki birikim oranları karşılaştırılmıştır. Örneğin tuz stresine duyarlı olan pirinç [163] ve domates [164] bitkilerinde poliamin birikiminin daha belirgin olduğu ortaya çıkarılmıştır. Daha farklı stres tiplerinin de bitkilerde poliamin miktarında değişimlere neden olması, poliamin birikiminin sadece tuz stresine spesifik olmadığını göstermektedir [13, 160].

\subsection{Antioksidant Sistem}

Tuz stresi altındaki bitkilerde özellikle kloroplast ve mitokondrilerdeki elektron taşınım reaksiyonları sırasında ara ürün olarak süperoksit radikali $\left(\mathrm{O}_{2}^{--}\right)$, hidrojen peroksit $\left(\mathrm{H}_{2} \mathrm{O}_{2}\right)$, hidroksil radikali $\left(\mathrm{OH}^{-}\right)$ve tekli uyarılmış oksijen $\left({ }^{1} \mathrm{O}_{2}\right)$ gibi farklı AOT' ler oluşabilir. Normal koşullar altında AOT' ler bitki dokularındaki çeşitli antioksidant savunma mekanizmaları ile detoksifiye edilir [165]. Ancak tuzluluk da dahil birçok stres faktörü bitki hücrelerinde AOT' lerin oluşum ve detoksifikasyon hızı arasındaki dengeyi bozabilir. Sonuçta AOT' lerin hücre içindeki miktarı hızla artış gösterir [166]. AOT' ler nükleik asitlerde hasar oluşturarak, proteinleri okside ederek ve lipid peroksidasyonuna neden olarak birçok hücresel fonksiyonda bozulmalara neden olur [165]. Bu nedenle farklı çevresel stres faktörlerinin etkisiyle bitki dokularında meydan a gelen AOT' ler ürün kayıplarının temel sebebi olarak kabul edilmektedir [167].

Bitkiler, AOT' lerin toksik etkilerinden kendilerini korumak için etkili bir antioksidant sistem geliştirmiştir. Antioksidant sistem, enzimatik ve enzimatik olmayan bileşenlerden oluşur. Süperoksid dismutaz (SOD), askorbat peroksidaz (APOD), glutatyon redüktaz (GR), dehidroaskorbat redüktaz (DHAR), monodehidroaskorbat redüktaz (MDHAR), guaiakol peroksidaz (GPOD), ve katalaz (KAT) bu sistemin önemli bazı enzimatik bileşenlerini oluşturur. Askorbik asit (C vitamini), glutatyon, karotenoidler, flavonoidler ve $\alpha$ tokoferol (E vitamini) ise enzimatik olmayan antioksidant bileşiklerdir. 
$\mathrm{SOD}, \mathrm{O}_{2}{ }^{--}$radikalinin bir dismutayon reaksiyonu ile $\mathrm{H}_{2} \mathrm{O}_{2}$ ' ye indirgenmesiyle ilgili reaksiyonu katalizler. Böylece $\mathrm{O}_{2}$ radikalini detoksifiye ederek Haber-Weiss reaksiyonu ile $\mathrm{OH}^{-}$radikalinin oluşma olasılığını azaltır. SOD aktivitesinin biyotik ve abiyotik stres faktörleri altındaki bitki dokularında artış göstermesi, stres toleransının gelişmesi bakımından önemlidir. Dut, nohut, domates ve misır gibi bitki türlerinde tuz uygulamaları sonucunda SOD aktivitesinde artış meydana geldiği rapor edilmiştir [168, 169, 170, 8]. Pan ve arkadaşları (2006) da Glycyrrhiza uralensis bitkisinde tuz stresi etkisiyle SOD aktivitesinin artış gösterdiğini bildirmişlerdir [171]. Benzer şekilde Yu ve Rengel (1999) acı bakla bitkisinde, Ahmad ve arkadaşları (2010) dut bitkisinde tuz stresinin SOD aktivitesini artırdığını belirlemişlerdir [172, 173]. Öte yandan MnSOD genini yüksek derecede ekspresleyen transgenik Arabidopsis ve domates bitkilerinde de tuz stresi uygulamaları SOD aktivitesinin artmasına neden olmuştur [174, 175]. APOD bitki hücrelerinde su-su döngüsü ve askorbat-glutatyon döngüsünde yer alan enzimlerden biridir ve $\mathrm{H}_{2} \mathrm{O}_{2}$ ' nin parçalanmasından sorumludur. $\mathrm{H}_{2} \mathrm{O}_{2}$ ' ye afinitesi oldukça yüksek olduğu için bitkilerde $\mathrm{H}_{2} \mathrm{O}_{2}$ ' nin detoksifikasyonu konusunda en etkili enzimdir. Srivastava ve arkadaşları (2005) tuz stresi uyguladıkları Anabaena doliolum' da APOD aktivitesinin arttığını bildirmişlerdir [176]. Mittova ve arkadaşları (2002) farklı domates genotipleri ile yaptığ çalışmada, tuz tolerans derecesi ile APOD aktivitesindeki artı̧̧ arasında bir korelasyon bulunduğunu rapor etmişlerdir [177]. Benzer şekilde Citrus bitkilerinde de tuz toleransı ile artan APOD aktivitesi arasında bir ilişkinin olduğu ileri sürülmüştür [178]. Hem prokaryot hem de ökaryot canlılarda bulunan GR bir flavo-protein oksidoredüktazdır [179]. GR, APOD gibi askorbat-glutatyon döngüsünde rol oynayan bir enzimdir ve indirgenmiş glutatyon havuzunu besleyerek AOT' lere karşı savunmanın önemli bir parçasını oluşturur. GR büyük oranda kloroplastlarda bulunmasına ragmen, mitokondri ve sitoplazmada da gözlenmiştir [180]. GR, okside durumdaki glutatyonu (GSSG) NADPH molekülünden aldığı bir elektronu kullanarak indirgenmiş forma (GSH) dönüştürür [181]. GR aktivitesinde ve GSH miktarında meydana gelen değişimler bitki türlerinin çeşitli stres faktörlerine karşı tolerans geliştirmesinde oldukça önemlidir. Eyidoğan ve Öz (2005) nohut bitkisinin yaprak dokularında, Kukreja ve arkadaşları (2005) kök dokularında, Srivastava ve arkadaşları (2005) ise A. doliolum' da tuz stresi uygulamaları sonucu GR aktivitesinin arttığını bildirmişlerdir [182, 169, 176]. Doğru (2014) tuz stresi uyguladığ 3167 ve Bora adlı misır genotiplerinde tuz stresinin GR aktivitesini artırdığını rapor etmiştir [8]. Hernandez ve arkadaşları (1999) bezelye bitkisinde, Parida ve arkadaşları (2004) ise Bruguiera parviflora bitkisinde tuz stresinin GR aktivitesini artırdığını gözlemlemişlerdir [55, 6]. MDHAR kloroplastik ve sitoplazmik izozimleri bulunan bir flavin adenin dinükleotid enzimidir. MDHAR enzimi APOD ile birlikte mitokondri ve peroksizomlarda $\mathrm{H}_{2} \mathrm{O}_{2}$ ' nin detoksifikasyonundan sorumludur [183]. Transgenik tütün bitkilerinde MDHAR geninin aşırı ekspresyonunun tuz toleransını artırdığı belirlenmiştir [184]. DHAR enzimi oksitlenmiş askorbik asitten indirgenmiş askorbik asidin oluşumunu sağlayan reaksiyonu katalizler. Hücrelerde stres faktörlerinin neden olduğu AOT birikimine karşı tolerans için indirgenmiş askorbat miktarının regülasyonu oldukça önemlidir. DHAR enziminin aktivitesindeki artışlar da birçok abiyotik stres faktörüne karşı geliştirilen tolerans için gereklidir. Tütün ve Arabidopsis bitkilerinde de tuz toleransı ile DHAR enziminin aktivitesindeki artışlar arasında bir korelasyonun bulunduğu ortaya çıkarılmıştır [185, 184]. Tuz stresi uygulanan Cicer arietinum bitkisinde de DHAR aktivitesinin artmasıyla birlikte tuz toleransının da $\operatorname{arttığ~}$ rapor edilmiştir [186]. Hernandez ve arkadaşları (1999) ise bezelye yapraklarındaki DHAR aktivitesinin sadece yüksek tuz konsantrasyonlarında (130-160 mM) indüklendiğini belirtmişlerdir [55]. Katalaz enzimi tetramer yapısına sahip olan, hem içeren ve $\mathrm{H}_{2} \mathrm{O}_{2}$ ' nin doğrudan doğruya su ve oksijene dönüşümünü sağlayan reaksiyonu katalizleyen bir enzimdir. Stres koşulları altındaki bitkilerde AOT' lerin detoksifikasyonu için önemli bir fonksiyone sahiptir [23]. Eyidoğan ve Öz (2005), tuz stresi altındaki nohut yapraklarında katalaz aktivitesinin önemli derecede arttığını belirlemiştir [182]. Benzer şekilde nohut bitkisinin kökerinde de tuz stresinin katalaz aktivitesini artırdığ belirlenmiştir [169]. A. doliolum' da ise tuz stresinin katalaz aktivitesini azalttığı rapor edilmiştir [176]. Katalaz aktivitesinin tuz stresine maruz birakılan soya, [187], salatalık [188], dut [189] ve hardal bitkilerinde [57] arttığı da ortaya çıkarılmıştır. GPOD temelde IAA' nın parçalanmasından, lignin biyosentezinden ve $\mathrm{H}_{2} \mathrm{O}_{2}$ ' yi parçalayarak biyotik stres faktörlerine karşı bir savunma mekanizması oluşturmaktan sorumludur. Vigna radiata [190] ve Oryza sativa [191] bitkilerinin yapraklarında, tuz stresi uygulamaları sonucu GPOD aktivitesinin arttı̆̆ belirtilmiştir. Doğru (2014) ise tuz stresi altındaki mısır genotiplerinden 3167 ve 32K61 genotiplerinin yapraklarındaki GPOD aktivitesinin arttığını, Bora genotipinde ise azaldığını ve GPOD aktivitesindeki değişimlerin genotipe bağlı olarak farklılık gösterdiğini belirlemiştir [8]. Tuz stresinin duyarlı bir domates genotipinin köklerinde GPOD aktivitesini azalttı̆̆ 1 , ancak toleranslı genotipte ise artırdığ1 gözlenmiştir [192]. GPOD ve diğer antioksidant enzimlerin bitkilerde tuz stresinin neden olduğu oksidatif hasarın boyutlarını azalttığ1 da bildirilmiştir [193, 194].

Askorbik asit bitkilerde yaygın olarak bulunan, AOT' lerin neden olduğu oksidatif hasarları minimum seviyeye indiren veya tamamen ortadan kaldıran, suda çözünme özelliğine sahip olan antioksidant bir moleküldür [195]. İndirgenmiş askorbik asidin rejenerasyonu bitki metabolizması açısından oldukça önemlidir. Çünkü okside formdaki askorbik asit (dehidro askorbik asit; DHA), indirgenmediği taktirde çok kısa bir süre içinde parçalanabilir. Askorbik asit en etkili AOT temizleyicisi olarak kabul edilir. Çünkü birçok enzimatik ve enzimatik olmayan reaksiyona, gereksinim duydukları elektronları askorbik asit sağlamaktadır. Askorbik asit aynı zamanda $\mathrm{O}_{2}^{--}$ve $\mathrm{OH}^{--}$radikallerini detoksifiye ederek ve tokoperoksi radikallerinden $\alpha$ tokoferol oluşumunu sağlayarak, membranları AOT' lerin neden olabileceği hasarlara karşı korur. Diğer yandan 
askorbik asit, violoksantin de-epoksidaz enzimi için kofaktör olarak görev yapar ve absorblandıktan sonra kullanılamayan ve fotosentetik birimlere zarar verebilecek olan aşırı 1 şık enerjisinin tüketilmesini sağlar [196]. Yapraklardaki askorbik asit miktarı ile bitkilerin stres faktörlerine tolerans dereceleri arasında bir ilişki olduğu bildirilmiştir. Örneğin yapraklarındaki askorbik asit miktarı yüksek olan tütün ve kavak bitkilerinde oksidatif stres hasarlarının azaldığ edilmiştir [197]. Doğru (2014), tuz stresinin bazı misır genotiplerinin yapraklarındaki indirgenmiş askorbik asit miktarını artırırken, okside formdaki askorbik asit miktarını azalttığını belirlemiştir [8]. Agarwal ve Shaheen (2007) de tuz stresi altındaki Momordica charantia bitkilerinin yapraklarındaki askorbik asit miktarının kontrole göre arttığını ortaya çıkarmıştır [198]. Farklı bitki türlerinde yapılan çalışmalar da tuz stresinin yapraklardaki askorbik asit miktarını artırdığını göstermiştir [199, 6]. Glutamin, sistein ve glisin amino asitlerinden oluşan ve bir tripeptid olan glutatyon, bitkilerde AOT' lerin neden olduğu oksidatif strese karşı en önemli savunma mekanizmalarından birini oluşturmaktadır. Glutatyonun bitkilerde AOT' lerin neden olduğu oksidatif strese karşı savunmada rol oynayabilmesi için indirgenmiş formda bulunması gerekmektedir [200]. Glutatyon; ${ }^{1} \mathrm{O}_{2}, \mathrm{H}_{2} \mathrm{O}_{2}$ ve en toksik AOT olan $\mathrm{OH}^{--}$radikalinin potansiyel temizleyicisidir [201]. Glutatyon ayrıca, askorbat-glutatyon döngüsünde indirgenmiş askorbik asidin oluşumunu sağlayarak, antioksidant savunma sisteminde önemli bir fonksiyonu yerine getirir. Şiddetli strese maruz kalan bitkilerde genellikle indirgenmiş glutatyon miktarının azaldığ1, redoks durumunun bozularak bitki dokularında okside formdaki glutatyon miktarının arttığı ve oksidatif hasarların meydana geldiği belirlenmiştir [202]. Creissen ve arkadaşları (1999), Vigna radiata' nın tuza toleranslı olan Pusa Bold adlı genotipinin yapraklarındaki indirgenmiş glutatyon miktarının daha yüksek olduğunu ve bu genotipte meydana gelen oksidatif hasarın boyutlarının da daha düşük olduğunu bildirmişlerdir [203]. Glutatyonun farklı stres koşulları altında fotosentetik aygıtın oksidatif hasara karşı

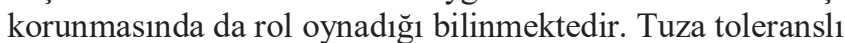
olan Brassica napus bitkilerinde, glutatyon miktarındaki artışın tuz stresinin olumsuz etkilerini azalttığı belirlenmiştir [204]. Gossett ve arkadaşları (1996) da, tuza toleranslı olan pamuk genotiplerinde indirgenmiş glutatyon miktarının duyarlı olanlara göre daha yüksek olduğunu rapor etmiştir [205]. İndirgenmiş glutatyon aynı zamanda AOT' lerin detoksifikasyonunda rol oynayan glutatyon transferaz ve glutatyon peroksidaz gibi enzimler için bir substrat niteliğindedir [206]. Tokoferoller, yağda çözünme özelliğine sahip olan, AOT ve lipid radikallerinin detoksifikasyonunda rol oynayan moleküllerdir [207]. Kloroplastların tilakoid membranlarunda lokalize olan tokoferoller, ${ }^{1} \mathrm{O}_{2}$, yi detoksifiye ederek membran stabilitesini sağlar. Tokoferollerin bitkilerde bulunan dört farklı izomerinden $(\alpha-$ , $\beta$-, $\gamma$ - ve $\delta$-) sadece $\alpha$-tokoferol, sahip olduğu üç tane metil grubundan dolayı en kuvvetli antioksidant aktiviteye sahiptir [208]. Gelişmiş bitkilerde tokoferollerin sentezinden sorumlu genlerin ekspresyonunun oksidatif stresle indüklenebileceği bildirilmiştir [209]. Tuz stresi altındaki $A$. doliolum' da $\alpha$-tokoferol miktarının artış gösterdiği ortaya çıkarılmıştır [176]. Trebst ve arkadaşları (2002), oksidatif stres altındaki Chlamydomonas reinhardtii' de fotosentetik aktivitenin korunması için $\alpha$-tokoferol miktarının yüksek olması gerektiğini rapor etmişlerdir [210]. Farouk (2011), buğday yapraklarında tuz stresinin indüklediği yaprak senesensinin $\alpha$ - tokoferol ile yavaşlatıldığını bulmuştur [211]. $\alpha$-tokoferolün özellikle tilakoid membranlarda lipid peroksil radikallerini etkisiz hale getirerek lipid peroksidasyon oranını azalttığı belirlenmiştir [212]. Karotenoid grubu pigmentlerden olan $\beta$-karoten; aşırı 1 şık enerjisini ortama 1si olarak vererek veya AOT' leri detoksifiye edip lipid peroksidasyonunu yavaşlatarak tüm fotosentetik organizmalarda 1şı̆̆ın neden olabileceği hasarlara karşı koruma sağlar. Bunun dişında karotenoidler; üçlü uyarılmış klorofil molekülünün $\left(\mathrm{klo}^{3}\right),{ }^{1} \mathrm{O}_{2}$ ve fotosentez sırasında oluşabilecek diğer AOT' lerin zararlı etkilerine karşı fotosentetik aygıtın korunmasını sağlamaktadır [213]. Yapılan bir çalışmada $100 \mathrm{mM}$ konsantrasyonunda tuz uygulanan pirinç yapraklarında karotenoid miktarının kontrole göre \%36 oranında azaldığı belirlenmiştir [50]. Vigna radiata' da artan tuz konsantrasyonlarının yapraklardaki karotenoid ve ksantofil pigmentlerinin miktarını azalttığı gözlenmiştir [214]. Benzer şekilde tuz stresi altındaki Greviela arenaria, domates ve B. parviflora bitkilerinin yapraklarındaki toplam karotenoid miktarının azaldığ1 rapor edilmiştir [48, 46, 215]. Yapılan bazı çalışmalarda da tuz stresinin yonca ve arpa bitkilerinin yapraklarındaki toplam karotenoid miktarını etkilemediği belirlenmiştir [216, 217]. Hefni ve Abdel-Kader (2006) ise toleranslı sorgum genotiplerinde tuz uygulamaları sonucunda yapraklardaki toplam karotenoid miktarının kontrollere göre artış gösterdiğini ve bunun tuz toleransı konusunda bir seleksiyon kriteri olarak kullanılabileceğini belirtmiştir [218].

Stres altındaki bitkilerde antioksidant sistemin etkinliğinde meydana gelen değişimlerin araştırılması oldukça önemlidir. Çünkü bu değişimler farklı bitki türlerinin ve aynı türe ait farklı genotiplerin herhangi bir stres faktörüne karşı tolerans ve duyarlılık derecesi hakkında bilgiler sağlamaktadır.

\section{SONUÇ}

Günümüzde farklı sebeplerden dolayı yeryüzündeki tarımsal alanlarda tuz birikimi sürekli artmakta ve bu da hem ürün miktarını hem de ürün kalitesini azaltmaktadır. Bu tip arazilerin, tuz miktarının azaltılması ile tekrar tarıma uygun duruma getirilmesi hemen hemen imkansızdır. Bu durumda tarımsal verimliliği artırmak için atılması gereken en önemli adım ekonomik öneme sahip olan bitki türlerinin tuza tolerans derecelerinin belirlenmesi ve buna uygun tarımsal yaklaşımların geliştirilmesidir. Bitkilerde tuz toleransı ile ilgili potansiyel fizyolojik ve biyokimyasal parametreler şekil 7' de özetlenmiştir. Tuz stresi bitkilerde fotosentetik aktiviteyi azaltmaktadır. Bunun sonucunda bitkilerde kuru madde birikimi ve büyüme hızı da azalmaktadır. Tuz stresi ayrıca bitkilerin topraktan aldıkları su miktarını azaltmakta ve mineral madde beslenmesini de olumsuz etkilemektedir. Ancak tuz stresi koşullarında fotosentetik aktivitesini ve 
büyümesini belli oranda devam ettirebilen tür ve genotipler tuza toleranslı olarak kabul edilmektedir. Toleranslı bitkiler aynı zamanda tuz stresi altında hücresel ozmoregülasyondan sorumlu olan çözünür karbohidrat, çözünür protein, bazı amino asitler, kuaterner amonyum bileşikleri ve polioller gibi bileşikleri dokularında biriktirerek topraktan su alınımını devam ettirebilmektedir. Dokularda uygun hormonal değişimlerin meydana gelmesi de bitkilerde tuz toleransının gelişmesine katkıda bulunmaktadır. Ayrıca antioksidant enzim aktivitelerinde ve antioksidant moleküllerin miktarında uygun değişimlerin meydana gelmesi de bitkilerde tuz toleransının gelişmesi için önemlidir.

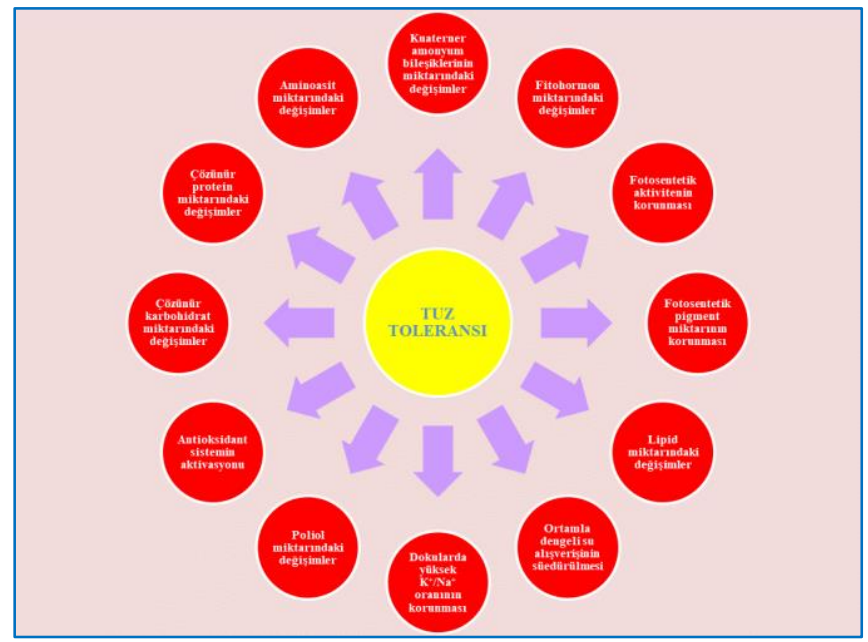

Şekil 7. Bitkilerde tuz toleransının gelişmesi ile ilgili fizyolojik ve biyokimyasal parametreler.

Bitkilerde tuz toleransının gelişmesi ile ilgili birçok fizyolojik ve biyokimyasal mekanizmanın varlığı söz konusudur. $\mathrm{Bu}$ nedenle bitkilerde tuz toleransinın anlaşılması oldukça zordur. Ayrıca bu mekanizmaların hiçbiri bitkilerde tuz toleransının sağlanması konusunda tek başına etkili değildir. $\mathrm{Bu}$ durumda bu mekanizmaların tuz toleransının gelişmesi konusunda sağladıkları katkının ve aralarındaki etkileşimlerin de ortaya çıkarılması gerekmektedir. $\mathrm{Bu}$ tip bilgilerin elde edilmesi, 1slah çalışmaları ile tuza toleranslı genotiplerin geliştirilmesi konusunda da faydalı olacaktır.

\section{KAYNAKÇA}

[1] S. Allakhverdiev, A. Sakamoto, Y. Nishimaya, M. Inaba and N. Murata, "Ionic and osmotic effects of NaCl-induced inactivation of photosystems I and II in Synechococcus sp.", Plant Physiol., 123, 1047-1056, 2000.

[2] J. C. Russel, L. Kadry and A. B. Hanna, "Sodic soils in Iraq", Agrokomiya ES Talajtan, 14, 91-97, 1965.

[3] K. N. Singh and C. Chatrath, Salinity tolerance, CIMMYT, Mexico, 2001.

[4] D. Rhoades and P. J. Rich, "Preliminary genetic studies of the phenotype of betaine deficiency in Zea mays L.", Plant Physiol., 88, 102-108, 1988.
[5] E. Yılmaz, A. L. Tuna ve B. Bürün, "Bitkilerin Tuz Stresi Etkilerine Karşı Geliştirdikleri Tolerans Stratejileri", CBÜFBD, 7, 47-66, 2011.

[6] A. K. Parida, A. B. Das and P. Mohanty, "Investigations on the antioxidative defense responses to $\mathrm{NaCl}$ stress in a mangrove, Bruguiera parviflora: differential regulations of isoforms of some antioxidative enzymes", Plant Growth Reg., 42, 213-226, 2004.

[7] M. Hasanuzzaman, M. Fujita, M. N. Islam, K. U. Ahamed and K. Nahar, "Performance of four irrigated rice varieties under different levels of salinity stress", IJIB, 6, 8590, 2009.

[8] A. Doğru, "Farklı misır genotiplerinde tuz stresinin antioksidant sistem üzerindeki etkileri”, 22. Ulusal Biyoloji Kongresi 2014, Osmangazi Üniversitesi, Eskişehir, 430, (2014).

[9] S. Zaimoğlu ve A. Doğru, "Farklı mısır genotiplerinde tuz stresinin bazı büyüme parametreleri ve fotosentetik aktivite üzerindeki etkileri", 23. Ulusal Biyoloji Kongresi 2016, Gaziantep Üniversitesi, Gaziantep, 270, (2016).

[10] P. Ahmad and S. Sharma, "Physio-biochemical attributes in two cultivars of mulberry $(M$. alba) under $\mathrm{NaHCO}_{3}$ stress”, Int. J. Plant Produc., 4, 79-86, 2010.

[11] E. P. Murakeozy, Z. Nagy, C. Duhaze, A. Bouchereau and Z. Tuba, "Seasonal changes in the levels of compatible osmolytes in three halophytic species of inland saline vegetation in Hungary", J. Plant Physiol., 160, 395-401, 2003.

[12] M. A. Wimmer, K. H. Muhling, A. Läuchli, P. H. Brown and H. E. Goldbach, "The interaction between salinity and boron toxicity affects the subcellular distribution of ions and proteins in wheat leaves", Plant Cell Environ., 26, 12671274, 2003.

[13] M. M. F. Mansour, "Nitrogen containing compounds and adaptation of plants to salinity stress", Biol. Plant., 43, 491-500, 2000.

[14] W. J. Yang, P. J. Rich, J. D. Axtell, K. V. Wood, C. C. Bonham, G. Ejeta, M. V. Mickelbart and D. Rhodes, "Genotypic variation for glycinebetaine in sorghum", Crop Sci., 43,162-169, 2003.

[15] T. Abebe, A. C. Guenzi, B. Martin and J. C. Cushman, "Tolerance of mannitol-accumulating transgenic wheat to water stress and salinity", Plant Physiol., 131, 1748-1755, 2003.

[16] L. Kerkeb, J. P. Donaireand M. P. Rodriguez-Rosales, "Plasma membrane $\mathrm{H}^{+}$-ATPase activity is involved in adaptation of tomato calli to $\mathrm{NaCl}$ ", Physiol. Plant., 111, 483-490, 2001.

[17] I. Aziz and M. A. Khan, "Experimental assessment of salinity tolerance of Ceriops tagal seedlings and saplings from the Indus delta, Pakistan", Aquat. Bot., 70, 259-268, 2001.

[17] J. M. Ribaut and P. E. Pilet, "Water stress and indole-3acetic acid content of maize roots", Planta 193, 502-507, 1994.

[18] T. Hisamatsu, M. Koshioka., S. Kubota, Y. Fujime, R. W. King and L. N. Mander, "The role of gibberellin in the control of growth and flowering in Matthiola incana", Physiol. Plant., 109, 97-105, 2000. 
[19] P. D. Hare, W. A. Cress and J. van Staden, "The involvement of cytokinins in plant responses to environmental stress", Plant Growth Reg., 23, 79-103, 1997. [20] N. Chakrabarti and S. Mukherji, "Alleviation of $\mathrm{NaCl}$ stress by pretreatment with phytohormones in Vigna radiata", Biol. Plant., 46, 589-594, 2003.

[21] G. R. Cramer and S. A. Quarrie, "Abscisic acid is correlated with the leaf growth inhibition of four genotypes of maize differing in their response to salinity", Funct. Plant Biol., 29, 111-115, 2002.

[22] H. Pedranzani, G. Racagni, S. Alemano, O. Miersch, I. Ramirez, H. Pena-Cortes, E. Taleisnik, E. MachadoDomenech and G. Abdala, "Salt tolerant tomato plants show increased levels of jasmonic acid", Plant Growth Reg., 41, 149-158, 2003.

[23] N. Garg and G. Manchanda, "ROS generation in plants: Boon or Bane", Plant Biosystems, 143, 8-96, 2009.

[24] V. Chinnusamy, A. Jagendorf and J. K. Zhu, "Understanding and improving salt tolerance in plants", Crop Sci., 45, 437-448, 2005.

[25] A. Kadıoğlu, Bitki Fizyolojisi, Trabzon: Efsen Ofset Matbaacilık, 2011.

[26] K. K. Tanji, Salinity in the soil environment, Dordrecht: Kluwer Academic Publishers, 2002.

[27] H. Marschner, Mineral Nutrition of Higher Plants, London: Academic Press, 1995.

[28] M. Tester and R. Davenport, " $\mathrm{Na}^{+}$tolerance and $\mathrm{Na}^{+}$ transport in higher plants", Ann. Bot., 91, 503-507, 2003.

[29] R. Munns, D. Schachtman and A. Condon, "The significance of a two-phase growth response to salinity in wheat and barley", Func. Plant Biol., 22, 561-569, 1995.

[30] P. M. Hasegawa, R. A. Bressan, J. K. Zhu and H. J. Bohnert, "Plant cellular and molecular responses to high salinity", Ann. Rev. Plant Physiol. Plant Mol. Biol., 51, 463499, 2000.

[30] R. Munns and M. Tester, "Mechanisms of salinity tolerance", Ann. Rev. Plant Physiol. Plant Mol. Biol., 59, 651-681, 2008.

[31] A. Läuchli and S. R. Grattan, Plant Growth and Development Under Salinity Stress, Netherlands: Springer, 2007.

[32] R. Munns, "Comparative physiology of salt and water stress", Plant Cell Environ., 25, 239-250, 2002.

[33] R. Davenport, R. James, A. Zakrisson-Plogander, M. Tester and R. Munns, Control of sodium transport in durum wheat", Plant Physiol., 137, 807-818, 2005.

[34] C. Foyer and G. Noctor, "Redox sensing and signalling associated with reactive oxygen in chloroplasts, peroxisomes and mitochondria", Physiol. Plantarum, 119, 355-364, 2003. [35] J. C. Papp, M. C. Ball and N. Terry, "A comparative study of the effects of $\mathrm{NaCl}$ salinity on respiration, photosynthesis, and leaf extension growth in Beta vulgaris L. (sugar beet)", Plant, Cell Environ., 6, 675-677, 1983.

[36] Y. Wang, N. Nil, "Changes in chlorophyll, ribulose biphosphate carboxylase-oxygenase, glycine betaine content, photosynthesis and transpiration in Amaranthus tricolor leaves during salt stress", J. Hortic. Sci. Biotechnol., 75, 623-627, 2000.
[37] K. Chartzoulakis and G. Klapaki, "Response of two green house pepper hybrids to $\mathrm{NaCl}$ salinity during different growth stages”, Sci. Hortic., 86, 247-260, 2000.

[38] L. F. M. Marcelis and J. van Hooijdonk, "Effect of salinity on growth, water use and nutrient use in radish (Raphanus sativus L.)", Plant and Soil, 215, 57-64, 1999.

[39] H. Kurban, H. Saneoka, K. Nehira, R. Adilla, G. S. Premachandra and K. Fujita, "Effect of salinity on growth, photosynthesis and mineral composition in leguminous plant Alhagi pseudoalhagi (Bieb.)", Soil Sci. Plant Nutr., 45, 851862, 1999.

[40] M. Mohammad, R. Shibli, M. Ajouni and L. Nimri, "Tomato root and shoot responses to salt stress under different levels of phosphorus nutrition", J. Plant Nutr., 21, 1667-1680, 1998.

[41] D. A. Meloni, M. A. Oliva, H. A. Ruiz and C. A. Martinez, "Contribution of proline and inorganic solutes to osmotic adjustment in cotton under salt stress", J. Plant Nutr., 24, 599-612, 2001.

[42] S. Khatun and T. J. Flowers, "Effects of salinity on seed set in rice", Plant Cell Environ., 18, 61-67, 1995.

[43] S. Mittal, N. Kumari and V. Sharma, "Differential response of salt stress on Brassica juncea: photosynthetic performance, pigment, proline, D1 and antioxidant enzymes”, Plant Physiol. Biochem., 54, 17-26, 2012.

[44] S. Mitsuya, Y. Takeoka and H. Miyake, "Effects of sodium chloride on foliar ultrastructure of sweet potato (Ipomoea batatas Lam.) plantlets grown under light and dark conditions in vitro", J. Plant Physiol., 157, 661-667, 2000.

[45] S. Bruns and C. Hecht-Buchholz, "Light and electronmicroscope studies on the leaves of several potato cultivars after application of salt at various developmental stages", Potato Res., 33, 33-41, 1990.

[46] R. A. Khavarinejad and Y. Mostofi, "Effects of $\mathrm{NaCl}$ on photosynthetic pigments, saccharides, and chloroplast ultrastructure in leaves of tomato cultivars", Photosynthetica, 35, 151-154, 1998.

[47] P. Agastian, S. J. Kingsley and M. Vivekanandan, "Effect of salinity on photosynthesis and biochemical characteristics in mulberry genotypes", Photosynthetica, 38, 287-290, 2000.

[48] B. F. Kennedy and L. F. De Fillippis, "Physiological and oxidative response to $\mathrm{NaCl}$ of the salt tolerant Grevillea ilicifolia and the salt sensitive Grevillea arenaria", J. Plant Physiol., 155, 746-754, 1999.

[49] A. N. M. Alamgir and M. Y. Ali, "Effect of salinity on leaf pigments, sugar and protein concentration and chloroplast ATPaz activity of rice (Oryza sativa L.)", Bangladesh J. Bot., 28, 145-149, 1999.

[50] S. Chutipaijit, S. Cha-um, and K. Sompornpailin, "High contents of proline and anthocyanin increase protective response to salinity in Oryza sativa L. spp. Indica", Aust. J. Crop Sci., 5, 1191-1198, 2011.

[51] K. Maxwell and G. N. Johnson, "Chlorophyll fluorescence-A practical guide”, J. Exp. Bot., 51, 659-668, 2000.

[52] R. Munns and A. Termatt, "Whole plant responses to salinity”, Aust. J. Plant Physiol., 13, 143-160, 1986. 
[53] J. Zhu and F. C. Meinzer, "Efficiency of C-4 photosynthesis in Atriplex lentiformis under salinity stress", Aust. J. Plant Physiol., 26, 79-86, 1999.

[54] M. P. Reddy, S. Sanish and E. R. R. Iyengar, "Photosynthetic studies and compartmentation of ions in different tissues of Salicornia brachiata Roxb. under saline conditions", Photosynthetica 26, 173-179, 1992.

[55] J. A. Hernandez, A. Campillo, A. Jimenez, J. J. Alacon and F. Sevilla, "Response of antioxidant systems and leaf water relations to $\mathrm{NaCl}$ stress in pea plants", New Phytol., 141, 241-251, 1999.

[56] R. Romeroaranda, T. Soria and J. Cuartero, "Tomato plant-water uptake and plant-water relationships under saline growth conditions", Plant Sci., 160, 265-272, 2001.

[57] P. Ahmad, K. R. Hakeem, A. Kumar, M. Ashraf and N. A. Akram, "Salt-induced changes in photosynthetic activity and oxidative defense system of three cultivars of mustard (Brassica juncea L.)", Afr. J. Biotechnol., 11, 2694-2703, 2012.

[58] M. Ashraf, "Some important physiological selection criteria for salt tolerance in plants", Flora, 199, 361-375, 2004.

[59] T. Matsumura, M. Kanechi, N. Inagaki and S. Maekawa, "The effects of salt stress on ion uptake, accumulation of compatible solutes, and leaf osmotic potential in safflower, Chrysanthemum paludosum and sea aster", J. Jpn. Soc. Hortic. Sci., 67, 426-431, 1998.

[60] K. Chaudhuri and M. A. Choudhuri, "Effect of shortterm $\mathrm{NaCl}$ stress on water relations and gas exchange of two jute species", Biol. Plant., 40, 373-380, 1997.

[61] S. Gulzar, M. A. Khan and I. A. Ungar, "Salt tolerance of a coastal salt marsh grass", Commun. Soil Sci. Plant Anal., 34, 2595-2605, 2003.

[62] C. M. Lu, N. W. Qiu, Q. T. Lu, B. S., Wang and T. Y. Kuang, "Does salt stress lead to increased susceptibility of photosystem II to photoinhibition and changes in photosynthetic pigment composition in halophyte Suaeda salsa grown outdoors", Plant Sci., 163, 1063-1068, 2002.

[63] W. J. Cram, Negative feedback regulation of transport in cells, Berlin: Springer-Verlag, 1976.

[64] M. Ashraf and M. Tufail, "Variation in salinity tolerance in sunflower (Helianthus annuus L.)", J. Agron. Soil Sci., 174, 351-362, 1995.

[65] M. Ashraf and H. Fatima, "Responses of some salt tolerant and salt sensitive lines of safflower (Carthamus tinctorius L.)", Acta Physiol. Plant., 61-71, 1995.

[66] C. G. Hounsa, E. V. Brandt, J. Thevelein, S. Hohmann and B. A. Prior, "Role of trehalose in survival of Saccharomyces cerevisiae under osmotic stress", Microbiology, 144, 671-680, 1998.

[67] O. J. M. Goddijn and K. van Dun, "Trehalose metabolism in plants", TIBS, 4, 315-319, 1999.

[68] M. A. Singer and S. Lindquist, "Multiple effects of trehalose on protein folding in vitro and in vivo", Molec. Cell., 1, 639-648, 1998.

[69] T. Yamada, Y. Takatsu, T. Manabe, M. Kasumi and W. Marubashi, "Suppressive effect of trehalose on apoptotic cell death leading to petal senescence in ethylene-insensitive flowers of gladiolus", Plant Sci., 164, 213-221, 2003.
[70] F. Fougere, D. Le Rudulier and J. G. Streeter, "Effects of salt stress on amino acid, organic acid, and carbohydrate composition of roots, bacteroids, and cytosol of alfalfa (Medicago sativa L.)", Plant Physiol., 96, 1228-1236, 1991. [71] A. K. Garg, J. K. Kim, T. G. Owens, A. P. Ranwala, Y. Do Choi, L. V. Kochian and R. J. Wu, "Trehalose accumulation in rice plants confers high tolerance levels to different abiotic stresses", PNAS, 99, 15898-15903, 2002.

[72] I. C. Jang, S. C. Oh, J. S. Seo, W. B. Choi, S. I. Song, C. H. Kim, Y. S. Kim, H. S. Seo, Y. Do Choi, B. H. Nahm and J. K. Kim, "Expression of a bifunctional fusion of the Escherichia coli genes for trehalose-6-phosphate synthase and trehalose-6-phosphate phosphatase in transgenic rice plants increases trehalose accumulation and abiotic stress tolerance without stunting growth", Plant Physiol., 131, 516524, 2003.

[73] G. Ali, P. S. Srivastava and M. Iqbal, "Proline accumulation, protein pattern and photosynthesis in regenerants grown under $\mathrm{NaCl}$ stress", Biol. Plant., 42, 8995, 1999.

[74] N. K. Singh, C. A. Bracken, P. M. Hasegawa, A. K. Handa, S. Buckel, M. A. Hermodson, F. Pfankoch, F. E. Regnier and R. A. Bressan, "Characterization of osmotin. A thaumatin-like protein associated with osmotic adjustment in plant cells", Plant Physiol., 85, 529-536, 1987.

[75] A. Pareek, S. L. Singla, and A. Grover, Salt responsive proteins/genes in crop plants, New Delhi: Oxford and IBH Publication, 1997.

[76] J. C. Thomas and H. J. Bohnert, "Salt stress perception and plant growth regulators in the halophyte Mesembryanthemum crystallinum”, Plant Physiol., 103, 1299-1304, 1993.

[77] W. J. Hurkman, H. P. Rao and C. K. Tanaka, "Germinlike polypeptides increase in barley roots during salt stress", Plant Physiol., 97, 366-374, 1991.

[78] Z. Q. Cheng, J. Targolli, X. Q. Huang and R. Wu, "Wheat LEA genes, PMA80 and PMA1959, enhance dehydration tolerance of transgenic rice (Oryza sativa L.)", Mol. Breed., 10, 71-82, 2002.

[79] A. Yamada, T. Saitoh, T. Mimura and Y. Ozeki, "Expression of mangrove allene oxide cyclase enhances salt tolerance in Escherichia coli, yeast, and tobacco cells", Plant Cell Physiol., 43, 903-910, 2002.

[80] W. J. Hurkman, C. S. Fornari and C. K. Tanaka, “A comparison of the effect of salt on polypeptide and translatable mRNA in roots of a salt tolerant and salt sensitive cultivar of barley", Plant Physiol., 90, 1444-1456, 1989.

[81] S. Uma, T. G. Prasad and M. U. Kumar, "Genetic variability in recovery growth and synthesis of stress proteins in response to polyethylene glycol and salt stress in finger millet", Ann. Bot., 76, 43-49, 1995.

[82] M. Ashraf and J. W. O'Leary, "Changes in soluble proteins in spring wheat stressed with sodium chloride", Biol. Plant., 42, 113-117, 1999.

[83] F. Sarhan and M. Perras, "Accumulation of a high molecular weight protein during cold hardening of wheat (Triticum aestivum L.)", Plant Cell Physiol., 28, 1173-1179, 1987. 
[84] M. Ashraf and A. Waheed, "Responses of some local/exotic accessions of lentil (Lens culinaris Medic.) to salt stress", J. Agron. Soil Sci., 170, 103-112, 1993.

[85] M. Ashraf, "Organic substances responsible for salt tolerance in Eruca sativa", Biol. Plant., 36, 255-259, 1994.

[86] B. Rabe, "Stress physiology: the functional significance of the accumulation of nitrogen containing compounds", J. Hort. Sci., 65, 231-243, 1990.

[87] R. S. Dubey, Photosynthesis in plants under stressful conditions, New York: Marcel Dekker, 1997.

[88] E. Abraham, G. Rigo, G. Szekely, R. Nagy, C. Koncz and L. Szabados, "Light- dependent induction of proline biosynthesis by abscisic acid and salt stress is inhibited by brassinosteroid in Arabidopsis", Plant Mol. Biol., 51, 363372, 2003.

[89] R. Storey, N. Ahmad and R. G. Wyn Jones, "Taxonomic and ecological aspects of the distribution of glycinebetaine and related compounds in plants", Oecologia 27, 319-322, 1977.

[90] T. Yamaya and H. Matsumoto, "Accumulation of asparagines in $\mathrm{NaCl}$-stressed barley seedlings", Ber. Ohara Ins. Land. Biol., 19, 181-188, 1989.

[91] M. A. A. Gadallah, "Effects of proline and glycinebetaine on Vicia faba responses to salt stress", Biol. Plant., 42, 249-257, 1999.

[92] A. Maggio, S. Miyazaki, P. Veronese, T. Fujita, J. I. Ibeas, B. Damsz, M. L. Narasimhan, P. M. Hasegawa, R. J. Joly and R. A. Bressan, "Does proline accumulation play an active role in stress induced growth reduction?", Plant J., 31, 699-712, 2002.

[92] S. J. M. Lutts, J. M. Kinet and J. Bouharmont, "Effects of salt stress on growth, mineral nutrition and proline accumulation in relation to osmotic adjustment in rice (Oryza sativa L.) cultivars differing in salinity tolerance", Plant Growth Regul., 19, 207-218, 1996.

[93] T. D. Colmer, E. Epstein and J. Dvorak, "Differential solute regulation in leaf blades of various ages in salt sensitive wheat and a salt-tolerant wheat x Lophopyrum elongatum (Host.) A. Love amphiploid", Plant Physiol., 108,1715-1724, 1995.

[94] M. I. Lone, J. S. H. Kueh, R. G. Wyn Jones and S. W. J. Bright, "Influence of proline and glycinebetaine on salt tolerance of cultured barley embryos", J. Exp. Bot., 38, 479490, 1987.

[95] A. B. Garcia, J. Almeida-Engler, S. Lyer, T. Gerats, M. Van Montagu and A. B. Caplan, "Effects of osmoprotectants upon $\mathrm{NaCl}$ stress in rice", Plant Physiol., 115, 159-169, 1997.

[96] I. Ahmad, S. J. Wainwright and G. R. Stewart, "The solute and water relations of Agrostis stolonifera ecotypes differing in their salt tolerance", New Phytol., 87, 615-629, 1981.

[97] S. Jain, H. S. Nainawatee, R. K. Jain and J. B. Chowdhury, "Proline status of genetically stable salt-tolerant Brassica juncea L. somaclones and their parent cv. Parkash", Plant Cell Rep., 9, 684-687, 1991.

[98] P. B. Kirti, S. Hadi and V. L. Chopra, "Seed transmission of salt tolerance in regenerants of Brassica juncea selected in vitro", Cruciferae News., 85, 14-15, 1991.
[99] S. Madan, H. S. Nainawatee, R. K. Jain and J. B. Chowdhury, "Proline and proline metabolizing enzymes in in vitro selected $\mathrm{NaCl}$-tolerant Brassica juncea $\mathrm{L}$. under salt stress", Ann. Bot., 76, 51-57, 1995.

[100] A. B. Moftah and B. B. Michel, "The effect of sodium chloride on solute potential and proline accumulation in soybean leaves", Plant Physiol., 83, 283-286, 1987.

[101] M. Ashraf, "The effect of $\mathrm{NaCl}$ on water relations, chlorophyll, and protein and proline contents of two cultivars of blackgram (Vigna mungo L.)", Plant Soil 119, 205-210, 1989.

[102] C. M. Grieve and E. M. Maas, "Betaine accumulation in salt stressed sorghum”, Physiol. Plant., 61, 167-171, 1984. [103] P. H. Yancey, M. B. Clark, S. C. Hands, R. D. Bowlus and G. N. Somero, "Living with water stress: evaluation of osmolyte systems", Science 217, 1214-1222, 1982.

[104] A. Mohanty, H. Kathuria, A. Ferjani, A. Sakamoto, P. Mohanty, N. Murata and A. K. Tyagi, "Transgenics of an elite indica rice variety Pusa Basmati 1 harbouring the $\operatorname{codA}$ gene are highly tolerant to salt stress", Theor. Appl. Genet., 106, 51-57, 2002.

[105] W. J. Yang, P. J. Rich, J. D. Axtell, K. V. Wood, C. C. Bonham, G. Ejeta, M. V. Mickelbart and D. Rhodes, "Genotypic variation for glycinebetaine in sorghum", Crop Sci., 43, 162-169, 2003.

[106] H. Genard, J. Le Saos, J. Hillard, A. Tremolieres and J. Boucaud, "Effect of salinity on lipid composition, glycinebetaine content and photosynthetic activity in chloroplasts of Suaeda maritima”, Plant Physiol. Biochem." 29, 421-427, 1991.

[107] N. Murata, P. S. Mohanty, H. Hayashi and G. C. Papageorgiou, "Glycinebetaine stabilizes the association of extrinsic proteins with the photosynthetic oxygen-evolving complex", FEBS Lett., 296, 187-189, 1992.

[108] A. D. Hanson and R. Grumet, Betaine accumulation: metabolic pathways and genetics, New York: Springer, 1985.

[109] H. Saneoka, C. Nagasaka, D. T. Hahn, W. J. Yang, G. S. Premachandra, R. J. Joly and D. Rhodes, "Salt tolerance of glycinebateine-deficient and -containing maize lines", Plant Physiol., 107, 631-638, 1995.

[110] R. F. McCue and A. D. Hanson, "Drought and salt tolerance: towards understanding and application", TIBTECH 8, 358-362, 1990.

[111] K. A. Varshney, L. P. Gangwar and N. Goel, "Choline and betaine accumulation in Trifolium alexandrinum $\mathrm{L}$. during salt stress", Egyptian J. Bot., 31, 81-86, 1988.

[112] H. J. Bohnert, B. Shen, "Transformation and compatible solutes”, Scient. Hort., 78, 237-260, 1999.

[113] A. J. Clark, K. J. Blissett and R. P. Oliver, "Investigating the role of polyols in Cladosporium fulvum during growth under hyper-osmotic stress and in planta", Planta, 216, 614-619, 2003.

[114] D. E. Nelson, M. Koukoumanos and H. J. Bohnert, "Myo-inositol-dependent sodium uptake in ice plant", Plant Physiol., 119, 165-172, 1999.

[115] B. Halliwell, M. Grootveld and J. M. C. Gutteridge, "Methods for the measurement of hydroxyl radicals in 
biochemical systems: deoxyribose degradation and aromatic hydroxylation", Methods Biochem. Anal., 33, 59-90, 1988. [116] J. F. Moran, M. Becana, I. Iturbe-Ormaetxe, S. Frechilla, R. V. Klucas and P. Aparicio-Tejo, "Drought induces oxidative stress in pea plants", Planta, 194, 346-352, 1994.

[117] N. Smirnoff and Q. J. Cumbes, "Hydroxyl radical scavenging activity of compatible solutes", Phytochem., 28, 1057-1060, 1989.

[118] M. C. Tarczynski, R. G. Jensen and H. J. Bohnert, "Expression of a bacterial $m t l D$ gene in transgenic tobacco leads to production and accumulation of mannitol", PNAS, 89, 2600-2604, 1992.

[119] B. Quemener and J. M. Brillouet, "Ciceritol, a pinitol digalactoside from seeds of chickpea, lentil and white lupin", Phytochem., 22, 1745-1751, 1983.

[120] J. Gorham, L. L. Hughes and R. G. Wyn Jones, "Lowmolecular-weight carbohydrates in some salt-stressed plants", Physiol. Plant., 53 27-33, 1981.

[121] J. Gorham, E. McDonnel and R. G. Wyn Jones, "Pinitol and other solutes in salt-stressed Sesbania aculeata", Z. Pflanzenphysiol., 114, 173-178, 1984.

[122] D. E. Nelson, G. Rammesmayer and H. J. Bohnert, "Regulation of cell specific inositol metabolism and transport in plant salinity tolerance", Plant Cell, 10, 753-764, 1998.

[123] E. Sheveleva, W. Chmara, H. J. Bohnert and R. G. Jensen, "Increased salt and drought tolerance by D-ononitol production in transgenic Nicotiana tabacum L.", Plant Physiol., 115, 1211-1219, 1997.

[124] S. C. Singh, R. P. Sinha and D. P. Hader, "Role of lipids and fatty acids in stress tolerance in cyanobacteria", Acta Protozool., 41, 297-308, 2002.

[125] A. M. Hassanein, "Alterations in protein and esterase patterns of peanut in response to salinity stress", Biol. Plant., 42, 241-248, 1999.

[126] J. L. Wu, D. M. Seliskar and J. L. Gallagher, "Stress tolerance in the marsh plane Spartina patens: impact of $\mathrm{NaCl}$ on growth and root plasma membrane lipid composition", Physiol. Plant., 102, 307-317, 1998.

[127] R. G. Ferreira, F. J. A. F. Tavora and F. F. F. Hernandez, "Dry matter partitioning and mineral composition of roots, stems and leaves of guava grown under salt stress conditions", Pesqui. Agropecu. Bras., 36, 79-88, 2001.

[128] H. Pedranzani, G. Racagni, S. Alemano, O. Miersch, I. Ramirez, H. Pena-Cortes, E. Taleisnik, E. MachadoDomenec and G. Abdala, "Salt tolerant tomato plants show increased levels of jasmonic acid", Plant Growth Regul., 41, 149-158, 2003.

[129] P. W. Morgan, Effects of abiotic stresses on plant hormone systems, New York: Wiley, 1990.

[130] Y. Wang, S. Mopper and K. H. Hasentein, "Effects of salinity on endogenous ABA, IAA, JA, and SA in Iris hexagona", J. Chem. Ecol., 27, 327-342, 2001.

[131] L. Prakash and G. Prathapasenan, "NaCl and gibberellic acid induced changes in the content of auxin, the activity of cellulose and pectin lyase during leaf growth in rice (Oryza sativa)", Ann. Bot., 365, 251-257, 1990.
[132] M. McConn, R. A. Creelman, F. Bell, J. E. Mullet and J. Browse, "Jasmonate is essential for insect defense in Arabidopsis", PNAS, 94, 5473-5477, 1997.

[133] J. Lehmann, R. Atzorn, C. Bruckner, S. Reinbothe, J. Leopold, C. Wasternack and B. Parthier, "Accumulation of jasmonate, abscisic acid, specific transcripts and proteins in osmotically stressed barley leaf segments", Planta, 197, 156$162,1995$.

[134] B. Kumar ve B. Singh, "Effect of plant hormones on growth and yield of wheat irrigated with saline water", Ann. Agric. Res., 17, 209-212, 1996.

[135] H. Nayyar, D. P. Walia and B. L. Kaistha, "Performance of bread wheat (Triticum aestivum L.) seed primed with growth regulators and inorganic salts", Indian J. Agric. Sci., 65, 116-122, 1995.

[136] M. A. Choudhuri, "Free radicals and leaf senescencea review", Plant Physiol. Biochem., 15, 18-29, 1988.

[137] D. S. Letham, Cytokinins, Amsterdam: Elsevier, 1978. [138] J. C. Thomas, E. F. McElwain and H. J. Bohnert, "Convergent induction of osmotic stress-responses: abscisic acid, cytokinin, and the effects of NaCl”, Plant Physiol., 100, 416-423, 1992.

[139] S. Bozcuk, "Effect of kinetin and salinity on germination of tomato, barley and cotton seeds", Ann. Bot., 48, 81-84, 1981.

[140] J. Boucaud and I. A. Ungar, "Hormonal control of germination under saline conditions of three halophyte taxa in genus Suaeda”, Physiol. Plant., 36, 197-200, 1976.

[141] S. S. M. Naqvi, R. Ansari and A. N. Kuawada, "Responses of salt stressed wheat seedlings to kinetin", Plant Sci. Lett., 26, 279-283, 1982.

[142] Z. Abdullah and R. Ahmad, "Effect of pre- and postkinetin treatments on salt tolerance of different potato cultivars growing on saline soils", J. Agron. Crop Sci., 165, 94-102, 1990.

[143] M. B. Kirkham, W. R. Gardner and G. C. Gerloff, "Internal water status of kinetin-treated, salt-stressed plants", Plant Physiol., 53, 241-243, 1974.

[144] D. Kuiper, J. Schuit and P. J. C. Kuiper, "Actual cytokinin concentrations in plant tissue as an indicator for salt resistance in cereals", Plant Soil, 123, 243-250, 1990.

[145] T. He and G. R. Cramer, "Abscisic acid concentrations are correlated with leaf area reductions in two salt-stressed rapid cycling Brassica species", Plant Soil, 179, 25-33, 1996. [146] E. Montero, C. Cabot, C. H. Poschenrieder and J. Barcelo, "Relative importance of osmotic-stress and ionspecific effects on ABA-mediated inhibition of leaf expansion growth in Phaseolus vulgaris", Plant Cell Environ., 21, 54-62, 1998.

[147] R. A. Creelman, H. S. Mason, R. J. Bensen, J. S. Boyer and J. E. Mullet, "Water deficit and abscisic acid cause differential inhibition of shoot versus root growth in soybean seedlings", Plant Physiol., 92, 205-214, 1990.

[148] W. J., Davies, F. Tardieu and C. L. Trejo, "How do chemical signals work in plants that grow in drying soil", Plant Physiol., 104, 309-314, 1994.

[149] W. D. Jeschke, A. D. Peuke, J. S. Pate and W. Hartung, "Transport, synthesis and catabolism of abscisic acid (ABA) in intact plants of castor bean (Ricinus communis L.) under 
phosphate deficiency and moderate salinity", J. Exp. Bot., 48, 1737-1747,1997.

[150] H. Jae-Ung and L. Youngsook, “Abscisic acid-induced actin reorganization in guard cells of dayflower is mediated by cytosolic calcium levels and by protein kinase and protein phosphatase activities", Plant Physiol., 125, 2120-2128, 2001 .

[151] E. Montero, C. Cabot, J. Barcelo and C. Poschenrieder, "Endogenous abscisic acid levels are linked to decreased growth of bush bean plants treated with NaCl", Physiol. Plant., 101, 17-22, 1997.

[152] G. N. Amzallag, H. R. Lerner and A. PoljakoffMayber, "Exogenous ABA as a modulator of response of sorghum to high salinity", J. Exp. Bot., 41, 1389-1394, 1990. [153] C. Wasternack and B. Hause, Jasmonates and octadecanoids-signals in plant stress response and development, New York: Academic Press, 2002.

[154] A. Moons, E. Prisen, G. Bauw and M. V. Montagu, "Antagonistic effects of abscisic acid and jasmonates on saltinducible transcripts in rice roots", Plant Cell, 92, 243-259, 1997.

[155] T. D. Tsonev, G. N. Lazova, Z. G. Stoinova and L. P. Popova, "A possible role for jasmonic acid in adaptation of barley seedlings to salinity stres", J. Plant Growth Regul., 17, 153-159, 1998.

[156] R. Kramell, R. Atzorn, G. Schneider, O. Miersch, C. Bruckner, J. Schmidt, G. Sembdner and B. Parthier, "Occurrence and identification of jasmonic acid and its amino acid conjugates induced by osmotic stress in barley leaf tissue", J. Plant Growth Regul., 14, 29-36, 1995.

[157] V. V. Kuznetsov, V. Y. Rakitin, N. G. Sadomov, D. V. Dam, L. A. Stetsenko and N. I. Shevyakova, "Do polyamines participate in long-distance translocation of stress signals in plants?”, Russ. J. Plant Physiol., 49, 120-130, 2002.

[158] R. Walden, A. Cordeiro and A. F. Tiburcio, "Polyamines: small molecules triggering pathways in plant growth and development", Plant Physiol., 113, 1009-1013, 1997.

[159] W. G. Hopkins, Introduction to Plant Physiology, New York: Wiley, 1999.

[160] R. R. Kakkar and V. R. Rai, Polyamines under salt stress, New Delhi: Oxford and IBH Publishing Co., 1997.

[161] I. Ivanova, A. Foudouli, S. Koshuchowa and S. Kozhukhova, "Effects of salt stress on guard cells and their abolition by phytohormones and polyamines", Fiziol. Rast., 17, 24-27, 1991.

[162] S. Das, A. Bose and B. Ghosh, "Effect of salt stress on polyamine metabolism in Brassica campestris", Phytochem., 39, 283-285, 1995.

[163] S. Katiyer and R. S. Dubey, "Salinity-induced accumulation of polyamines in germinating rice seeds differing in salt tolerance", Trop. Sci., 30, 229-240, 1990.

[164] A. Aziz, J. Martin-Tanguy and F. Larher, "Stressinduced changes in polyamine and tyramine levels can regulate proline accumulation in tomato leaf discs treated with sodium chloride", Physiol. Plant., 104, 195-202, 1998. [165] C. H. Foyer and G. Noctor, "Redox homeostis and antioxidant signaling: a metabolic interface between stress perception and physiological responses", Plant Cell, 17, 1866-1875, 2005.

[166] S. Bhattachrjee, "Reactive oxygen species and oxidative burst: roles in stress, senescence and signal transduction in plant", Curr. Sci., 89, 1113-1121, 2005.

[167] N. A. Khan and S. Singh, Abiotic Stress and Plant Responses, New Delhi: IK International, 2008.

[168] P. Harinasut, D. Poonsopa, K. Roengmongkol and R. Charoensataporn, "Salinity effects on antioxidant enzymes in mulberry cultivar", Sci. Asia, 29, 109-113, 2003.

[169] S. Kukreja, A. S. Nandval, N. Kumar, S. K. Sharma, V. Unvi and P. K. Sharma, "Plant water status, $\mathrm{H}_{2} \mathrm{O}_{2}$ scavenging enzymes, ethylene evolution and membrane integrity of Cicer arietinum roots as affected by salinity", Biol. Plant., 49, 305-308, 2005.

[170] M. Gapinska, M. Sklodowska and B. Gabara, "Effect of short- and long-term salinity on the activities of antioxidative enzymes and lipid peroxidation in tomato roots", Acta Physiol. Plant., 30, 11-18, 2008.

[171] Y. Pan, J. J. Wu and Z. L. Yu, "Effect of salt and drought stress on antioxidant enzymes activities and SOD isoenzymes of liquorice (Glycyrrhiza uralensis Fisch)", Plant Growth Regul., 49, 157-165, 2006.

[172] Q. Yu and Z. Rengel, "Drought and salinity differentially influence activities of superoxide dismutases in narrow-leafed lupins", Plant Sci., 142, 1-11, 1999.

[173] P. Ahmad, C. A. Jaleel and S. Sharma, "Antioxidative defence system, lipid peroxidation, proline metabolizing enzymes and biochemical activity in two genotypes of Morus alba L. subjected to $\mathrm{NaCl}$ stress", Russ. J. Plant Physiol., 57, 509-517, 2010.

[174] Y. Wang, Y. Ying, J. Chen and X. C. Wang, "Transgenic Arabidopsis overexpressing Mn-SOD enhanced salt-tolerance", Plant Sci., 167, 671-677, 2004.

[175] Y. Wang, M. Wisniewski, R. Meilan, S. L. Uratsu, M. G. Cui, A. Dandekar and L. Fuchigami, "Ectopic expression of Mn-SOD in Lycopersicon esculentum leads to enhanced tolerance to salt and oxidative stress", J. Appl. Horticul., 9, 3-8, 2007.

[176] A. K. Srivastava, P. Bhargava and L. C. Rai, "Salinity and copper-induced oxidative damage and changes in antioxidative defense system of Anabaena doliolum", J. Microb. Biotechnol., 22, 1291-1298, 2005.

[177] V. Mittova, M. Guy, M. Tal and M. Volokita, "Response of the cultivated tomato and its wild salt-tolerant relative Lycopersicon pennellii to salt-dependent oxidative stress: increased activities of antioxidant enzymes in root plastids”, Free Radic. Res., 36, 195-202, 2002.

[178] Y. Gueta-Dahan, Z. Yaniv, B. A. Zilinskas and G. BenHayyim, "Salt and oxidative stress: similar and specific responses and their relation to salt tolerance in citrus", Planta, 203, 460-469, 1997.

[179] M. C. Romero-Puertas, F. J. Corpas, L. M. Sandalio, M. Leterrier, M. Rodriguez Serrano, L. A. J. del Rio and M. Palma, "Glutathione reductase from pea leaves: response to abiotic stress and characterization of the peroxisomal isozyme", New Phytol., 170, 43-52, 2006.

[180] G. P. Creissen, P. Broadbent, B. Kular, H. Reynolds, A. R. Wellburn and P. M. Mullineaux, "Manipulation of 
glutathione reductase in transgenic plants: implications for plant responses to environmental stress", Proc. R. Soc. Edinb. 102B, 167-175, 1994.

[181] R. Chalapathi, A. S. V. Rao and A. R. Reddy, Glutathione reductase: a putative redox regulatory system in plant cells, The Netherlands: Springer, 2008.

[182] F. Eyidoğan and M. T. Öz, "Effect of salinity on antioxidant responses of chickpea seedlings", Acta Physiol. Plant., 29, 485-493, 2007.

[183] L. A. Del Rio, F. J. Corpas, L. M. Sandalio, J. M. Palma, M. Gomez and J. B. Barroso, "Reactive oxygen species, antioxidant system and nitric oxide in peroxisomes", J. Exp. Bot., 53, 1255-1272, 2002.

[184] A. E. Eltayeb, N. Kawano, G. H. Badawi, H. Kaminaka, T. Sanekata, T. Shibahara, S. Inanaga and K. Tanaka, "Overexpression of monodehydroascorbate reductase in transgenic tobacco confers enhanced tolerance to ozone, salt and polyethylene glycol stresses", Planta, 225, 1255-1264, 2007.

[185] T. Ushimaru, T. Nakagawa, Y. Fujioka, K. Daicho, M. Naito, Y. Yamaguchi, H. Nonaka, K. Amako, K. Yamawaki and N. Murata, "Transgenic Arabidopsis plants expressing the rice dehydroascorbate reductase gene are resistant to salt stress", J. Plant Physiol., 163, 1179-1184, 2006.

[186] S. Sheokand, V. Bhankar and V. Sawhney, "Ameliorative effect of exogenous nitric oxide on oxidative metabolism in $\mathrm{NaCl}$ treated chickpea plants", Braz. J. Plant Physiol., 22, 81-90, 2010.

[187] M. E. Comba, M. P. Benavides and M. L. Tomaro, "Effect of salt stress on atioxidant defence system in soybean root nodules", Aust. J. Plant Physiol., 25, 665-671, 1998.

[188] S. Lechno, E. Zamski and E. Tel-Or, "Salt stress induced responses in cucumber plants", J. Plant Physiol., 150, 206-211, 1997.

[189] C. Sudhakar, A. Lakshmi and S. Giridarakumar, "Changes in the antioxidant enzyme efficiacy in two high yielding genotypes of mulberry (Morus alba) under $\mathrm{NaCl}$ salinity", Plant Sci., 161, 613-619, 2001.

[190] S. K. Panda, "Response of green gram seeds under salinity stress", Indian J. Plant Physiol., 6, 438-440, 2001.

[191] Y. Koji, M. Shiro, K. Michio, T. Mitsutaka and M. Hiroshi, "Antioxidant capacity and damages caused by salinity stress in apical and basal regions of rice leaf', Plant Prod. Sci., 12, 319-326, 2009.

[192] V. Mittova, M. Guy, M. Tal and M. Volokita, "Salinity upregulates the antioxidative system in root mitochondria and peroxisomes of the wild salt-tolerant tomato species Lycopersicon pennellii”, J. Exp. Bot. 55, 1105-1113, 2004.

[193] R. G. Alscher, J. L. Donahue and C. L. Cramer, "Reactive oxygen species and antioxidants: relationship in green cells", Physiol. Plant., 100, 224-233, 1997.

[194] K. Apel and H. Hirt, "Reactive oxygen species: metabolism, oxidative stress, and signal transduction", Annu. Rev. Plant Biol., 55, 373-399, 2004.

[195] H. R. Athar, A. Khan and M. Ashraf, "Exogenously applied ascorbic acid alleviates salt-induced oxidative stress in wheat", Env. Exp. Bot., 63, 224-231, 2008.
[196] N. Smirnoff, "Ascorbic acid: metabolism and functions of a multifacetted molecule", Curr. Opin. Plant Biol., 3, 229-235, 2000.

[197] M. Aono, A. Kubo, H. Saji, K. Tanaka and N. Kondo, "Enhanced tolerance to photooxidative stress of transgenic Nicotiana tabacum with high chloroplastic glutathione reductase activity", Plant Cell Physiol., 34, 129-135, 1993. [198] S. Agarwal and R. Shaheen, "Stimulation of antioxidant system and lipid peroxidation by abiotic stresses in leaves of Momordica charantia ", Braz. J. Plant Physiol., 19, 149-161, 2007.

[199] S. K. Panda and R. K. Upadhyay, "Salt stress injury induces oxidative alterations and antioxidative defence in the roots of Lemna minor”, Biol. Plant., 48, 249-253, 2004.

[200] A. J. Meyer, "The integration of glutathione homeostasis and redox signaling”, Plant Physiol., 165, 13901403, 2008.

[201] L. O. Briviba and H. Klotz, "Toxic and signaling effects of photochemically or chemically generated singlet oxygen in biological systems", J. Biol. Chem., 378, 1259$1265,1997$.

[202] M. Tausz, H. Ircelj, H and D. Grill, "The glutathione system as a stress marker in plant ecophysiology: is a stressresponse concept valid?", J. Exp. Bot., 55, 1955-1962, 2004. [203] G. Creissen, J. Firmin, M. Fryer, B. Kular, N. Leyland, H. Reynolds, G. Pastori, F. Wellburn, N. Baker, A. Wellburn and P. Mullineaux, "Elevated glutathione biosynthetic capacity in the chloroplasts of transgenic tobacco plants paradoxically causes increased oxidative stress", The Plant Cell, 11, 1277-1291, 1999.

[204] T. M. Hussain, T. Chandrasekhar, M. Hazara, Z. Sultan, B. Z. Saleh and G. R. Gopal, "Recent advances in salt stress biology-a review", Biotechnol. Mol. Biol. Rev., 3, 8$13,2008$.

[205] D. R. Gossett, S. W. Banks, E. P. Millhollon and M. C. Lucas, "Antioxidant response to $\mathrm{NaCl}$ stress in a control and a $\mathrm{NaCl}$-tolerant cotton cell line grown in the presence of paraquat, buthionine sulfoximine and exogenous glutathione", Plant Physiol., 112, 803-809, 1996.

[206] G. Noctor, L. Gomez, H. Vanacker and C. H. Foyer, "Interactions between biosynthesis, compartmentation and transport in the control of glutathione homeostasis and signalling”, J. Exp. Bot., 53, 1283-1304, 2002.

[207] H. Hollander-Czytko, J. Grabowski, I. Sandorf, K. Weckermann and E. W. Weiler, "Tocopherol content and activities of tyrosine aminotransferase and cystine lyase in Arabidopsis under stress conditions", J. Plant Physiol., 162, 767-770, 2005.

[208] A. Kamal-Eldin and L. A. Appelqvist, "The chemistry and antioxidant properties of tocopherols and tocotrienols", Lipids, 31, 671-701, 1996.

[209] G. Wu, Z. K. Wei and H. B. Shao, "The mutual responses of higher plants to environment: physiological and microbiological aspects", Biointerfaces, 59, 113-119, 2007. [210] A. Trebst, B. Depka and H. Holländer-Czytko, “A specific role for tocopherol and of chemical singlet oxygen quenchers in the maintenance of photosystem II structure and function in Chlamydomonas reinhardtii", FEBS Lett., 516, 156-160, 2002. 
[211] S. Farouk, "Ascorbic acid and $\alpha$-tocopherol minimize salt-induced wheat leaf senescence", J. Stress Physiol. Biochem, 7, 58-79, 2011.

[212] H. Maeda, Y. Sakuragi, D. A. Bryant and D. DellaPenna, "Tocopherols protect Synechocystis sp. strain PCC 6803 from lipid peroxidation”, Plant Physiol., 138, 1422-1435, 2005.

[213] A. Collins, "Carotenoids and genomic stability", Mutat. Res., 475, 1-28, 2001.

[214] P. Saha, P. Chatterjee and A. K. Biswas, "NaCl pretreatment alleviates salt stress by enhancement of antioxidant defense system and osmolyte accumulation in mungbean (Vigna radiata L. Wilczek)", Indian J. Exp. Biol., 48, 593-600, 2010.

[215] A. Parida, A. B. Das and P. Das, "NaCl stress causes changes in photosynthetic pigments, proteins and other metabolic components in the leaves of a true mangrove, Bruguiera parviflora, in hydroponic cultures", J. Plant Biol., 45, 28-36, 2002.

[216] R. A. Khavarinejad and N. Chaparzadeh, "The effects of $\mathrm{NaCl}$ and $\mathrm{CaCl}_{2}$ on photosynthesis and growth of alfalfa plants", Photosynth., 35, 461-466, 1998.

[217] H. Çakırlar, N. Çiçek, I. Fedina, K. Georgieva A. Doğru and $\mathrm{M}$. Velitchkova, "NaCl induced crossacclimation to UV-B radiation in four barley (Hordeum vulgare L.) cultivars", Acta Physiol. Plant., 30, 561-567, 2008.

[218] M. Hefni and D. Z. Kader, Salinity and Water Stress, Netherlands: Springer, 2006. 